\title{
TRUSTS IN THE CONSTRUCTION INDUSTRY
}

\author{
BY L.P. ETTINGER*
}

The author examines the recommendations of the Joint Government/Industry Task Force on Builders' Liens, with particular emphasis on the use of a trust obligation to ensure payment. The article also deals with how this trust condition would operate.

\section{TABLE OF CONTENTS}

I. INTRODUCTION

II. IMPLICATIONS OF THE IMPOSITION OF

TRUST OBLIGATIONS ON AN INDUSTRY $\ldots \ldots \ldots \ldots$

III. LEGISLATIVE HISTORY OF TRUSTS

IN THE CONSTRUCTION INDUSTRY $\ldots \ldots \ldots \ldots \ldots \ldots$

IV. PROPOSALS FOR REFORM

A. British Columbia ....................... 395

B. Manitoba .......................... 395

C. Ontario ................................ 396

D. Saskatchewan ........................ 396

V. RECOMMENDATIONS OF THE TASK FORCE . . . . . . . 397

VI. THE NATURE OF THE STATUTORY TRUST $\ldots \ldots \ldots \ldots \ldots \quad 400$

A. A Trust Created by Statute $\ldots \ldots \ldots \ldots \ldots \ldots \ldots \ldots, 400$

B. Duties of a Builders' Lien Trustee ............... 402

i) Duty to Preserve Trust Assets $\ldots \ldots \ldots \ldots \ldots \ldots \ldots \ldots, 402$

ii) Distribution of Trust Funds $\ldots \ldots \ldots \ldots \ldots \ldots \ldots \ldots 403$

C. Set-Off $\ldots \ldots \ldots \ldots \ldots \ldots \ldots \ldots \ldots \ldots \ldots \ldots, 405$

D. To Whom the Duty is Owed . . . . . . . . . . . . . . 408

E. Remedies of the Beneficiary ................. 420

VII. APPRAISAL OF THE RECOMMENDATIONS

OF THE TASK FORCE FOR ALBERTA .......... 425

VIII. CONCLUSION ........................... 429

\section{INTRODUCTION}

The Joint Government/Industry Task Force on Builders' Liens was established by the Attorney General of Alberta on June 18, 1987. In September 1988 the Task Force released its Preliminary Report ${ }^{1}$ which contains, inter alia, recommendations for the inclusion of comprehensive trust provisions in builders' lien legislation in Alberta. Since the adoption of trust provisions in Alberta appears imminent and there has been little legal writing on the subject, ${ }^{2}$ this paper will examine these recommendations in some detail. The paper will begin with the nature of the

* Graduate Student of Law, University of Alberta.

1. Preliminary Report of the Joint Government/Industry Task Force on Builders' Liens, September, 1988 (Alberta)

2. See J.W. Mik, "The Trust Fund Provision of the Mechanics' Lien Act" (1966) 4:77 Osgoode Hall L.J. 77 and J.M. Roland, “Trust Provisions of Provincial Mechanics' Lien Legislation - Recent Developments"' (1964) 22 U.T. Fac. L.R. 107. 
statutory trust and the implications of the imposition of a statutory trust scheme on the construction industry. It will then review the legislative history of trust provisions in builders' lien legislation in Canada and the experience of Alberta to date. Finally, it will provide a critical analysis of the proposed trust scheme for the construction industry in Alberta.

\section{IMPLICATIONS OF THE IMPOSITION OF TRUST OBLIGATIONS ON AN INDUSTRY}

The construction industry in North America is often described as similar to a "pyramid" with the owner at the top or a "chain" with each party representing a link in the chain. In most instances the owner contracts with a general contractor, who then engages sub-trades who in turn have employees and suppliers. The end result is that most of the work is done and most materials supplied by persons with whom the owner has no contractual privity. Apart from the lien statutes, the persons at the end of the chain have a remedy against only the person employing them who in turn has a remedy against only the person employing him and so on up the chain. In addition the remedy available is simply for breach of contract which is a very limited remedy indeed if the defendent is insolvent which is often the case.

The remedy of the builders' lien developed to help alleviate this situation. It appears to have its roots in early Roman law; it is not a part of the English Common Law. ${ }^{3}$ In relatively young nations such as Canada and the United States, which were built virtually from the ground up in the past century, the remedy of the builders' lien was adopted and refined to alleviate some of the problems inherent in the pyramid model.

The basic rationale for the builders' lien is to prevent the unjust enrichment of an owner who has received the benefit of labour and materials to improve his land. ${ }^{4}$ As stated by Harvey J., as he then was, in Scratch v. Anderson, ${ }^{5}$ the purpose of the lien is to ensure that "the land which receives the benefit shall bear the burden". In the situation where the owner refuses or is unable to pay for improvements made to his land, those who contributed to the improvements are entitled to register a lien against the land and, ultimately, the land may be sold to satisfy the liens. Accordingly, the lien offers security to the contractor, subcontractors, suppliers and labourers as long as a portion of the price is unpaid by the owner. The principal object of builders' lien legislation is, therefore, to provide a remedy against the owner to those with whom there is no contractual privity.

Historically, the lien remedy was considered sufficient because the construction chain was relatively short. The lien remedy has serious limitations, however, and these problems are exacerbated as the construction chain lengthens. The lien remedy is effective only against the owner. Once the owner has paid the full contract price to the contractor, the lien remedy is not available and the only available tool to force funds down the chain is a suit for breach of contract. There is no special protection to prevent the contractor from using the funds either to finance

3. D. Macklem and D. Bristow, Construction and Mechanics' Liens in Canada (5th ed. 1985) p. 1.

4. See Hickey v. Stalker [1924] 1 D.L.R. 440 (Ont. C.A.); Earl F. Wakefield Co. v. Oil City Petroleums (Leduc) Led. [1958] S.C.R. 361; Brooks-Sanford Co. v. Theodore Telier Const. Co. (1910) O.L.R. 176 (C.A.); Re Shields and Winnipeg (1964) 47 D.L.R. (2d) 346 (Man. Q.B.)

5. [1917] 1 W.W.R. 1340 (Alta.) affm'd (sub nom. Limoges v. Scratch) 44 S.C.R. 86. 
other projects or for his personal benefit. As Rand J. explained in MinneapolisHoneywell Regulator Co. Ltd. v. Empire Brass Manufacturing Co. Ltd. ${ }^{6}$ in commenting on the British Columbia legislation,

The Act is designed to give security to persons doing work or fumishing materials in making an improvement on land. Speaking generally, the earlier sections give to such persons a lien on the land, but that is limited to the amount of money owing by the owner to the contractor under the contract when the notice of the lien is given to him: only thereafter does he pay the contractor at any risk.

For obvious reasons this is but a partial security; too often the contract price has been paid in full and the security of the land is gone. It is to meet that situation that $s .19$ (the trust provision) has been added. The contractor and subcontractor are made trustees of the contract moneys and the trust continues while employees, material men or others remain unpaid.

Also, even if the owner has not yet paid the full contract price, if the value of the improved land is less than the total of all encumbrances including liens, the owner may choose to walk away from the land. The land would then be sold, but assuming a mortgagee has priority, which is often the case, there is little, if anything, left for lien claimants. The owner would of course be subject to suit by the contractor for breach of contract (and possibly liable to the mortgagee on his covenant to pay) but in many cases the owner is insolvent and such judgments, if any, are empty remedies.

The introduction of a trust scheme to this scenario changes things dramatically. Under the trust scheme any money paid on account of the contract price is trust money and the recipient holds it in trust for the benefit of those to whom he owes a trust obligation, namely those with whom he has contracted for services or materials on the project. The trustee can discharge his trust obligations only by paying his beneficiaries and does not acquire a beneficial interest, or in other words cannot pay himself, until such time as he has discharged his trust obligations. Thus, funds paid on account of the contract price may not be diverted from persons down the chain by being used to pay debts incurred on other projects or to finance new projects. The trust therefore creates a structure whereby funds must flow down the chain until the last beneficiary has been paid. If funds do not flow there is likely a breach of trust, the remedy for which is much broader than simply the remedy for breach of contract. In an action for breach of trust the plaintiff may recover the trust property rather than being simply a judgment creditor. ${ }^{7}$ Also, the defendant may be subject to criminal and quasi-criminal sanctions and officers and directors of corporate defendants will not be able to hide behind the corporate veil if they knew or should have known about the breach of trust. ${ }^{8}$ In addition, where and to the extent that an owner is made a trustee of funds which he has identified as funding for the project, the owner too will be subject to action for breach of trust if he does not pay those funds. By extension of the trust obligation imposed on the owner, the owner is prevented from simply walking away from the project leaving only the land to satisfy creditors and claimants. Lastly, in the situation where an insolvency or bankruptcy occurs somewhere along the chain, the trust scheme ensures that funds continue to flow as funds impressed with the trust will not be available to the creditors of the insolvent or bankrupt party. ${ }^{9}$

6. [1955] S.C.R. 694, [1955] 3 D.L.R. 561, at p. 696 S.C.R.

7. D.W.M. Waters, Law of Trusts in Canada (2nd ed. 1984) p. 1033.

8. Macklem and Bristow, Construction and Mechanics' Liens in Canada, supra n. 3 at p. 400.

9. See the discussion on pp. 56-61 below. 
The trust scheme does have limitations however. The trust is effective only to the extent that there is trust property available. It does not guarantee payment where, for example, the contractor or subcontractor has underbid a job or where the right of set-off arises because of an incomplete or deficient job. In the situation of underbidding or of set-off, it is conceivable that a trust beneficiary will not be paid in full even though there has been no breach of trust anywhere in the chain. As long as a trustee pays all trust money he receives, he discharges his obligation even though his beneficiary is not paid in full. The trustee will not be able to pay himself, however, until such time as his beneficiaries have been fully satisfied.

\section{LEGISLATIVE HISTORY OF TRUSTS IN THE CONSTRUCTION INDUSTRY}

Manitoba was the first province to adopt a statutory trust scheme in its builders' lien legislation in $1932 .{ }^{10}$ Ontario introduced similar legislation in 1942. " British Columbia followed suit in 1948 and New Brunswick in 1959.12 Saskatchewan established a Royal Commission in 1962 to consider amendment of its builders' lien legislation and the Commissioner in his Report (known as the Thomson Report $)^{13}$ recommended against the adoption of trust provisions. When new legislation was introduced in 1973, however, it contained trust provisions similar to those in other provinces. ${ }^{14}$ Trust provisions were recommended in 1976 in Nova Scotia, but have not yet been adopted. ${ }^{15}$ Newfoundland has recently undertaken a review of its builders' lien legislation and the adoption of trust provisions was recommended in a Working Paper issued by the Newfoundland Law Reform Commission. ${ }^{16}$

Generally speaking, the trust provisions adopted by each province make the contractor and subcontractor trustee of any moneys received on account of the contract price until such time as all subcontractors, workmen, materialmen and suppliers have been paid. Exceptions are made allowing a builder, contractor or subcontractor who has paid for work or materials himself to be reimbursed with trust funds or a trustee who has paid for work or materials with borrowed funds to reimburse the lender with trust funds.

It is clear that the trust remedy is separate and distinct from the lien remedy. The lien is registered against the title of the improved land while the trust permits the beneficiary to pursue the money. While the lien is also a charge upon the lien fund (in Alberta the lien fund is comprised of the holdback made by the owner plus any funds owing by him under the contract at that time), that charge does not extend

10. The Builders and Workmen's Act, S.M. 1932, c.2, s.1.

11. The Statute Law Amendment Act, S.O. 1942, c.34, s.21.

12. Mechanics' Lien Amendment Act, S.B.C. 1948, c.48, s.2. An Act to Amend the Mechanics' Lien Act, S.N.B. 1959 , c.60, s.1.

13. Report of the Honourable Harold Francis Thomson, Q.C., Commissioner (Saskatchewan 1963).

14. The Mechanics' Lien Act, 1973, S.S. 1973, c.62.

15. See Report to the Attomey General of the Nova Scotia Law Reform Advisory Commission on Builders' Liens, 1976.

16. See Working Paper on the Mechanics' Lien Act: Certain Substantive Issues, Newfoundland Law Reform Commission, 1988. 
[VOL. XXVII, NO. 3

to create a cause of action for payment in favour of subtrades. ${ }^{17}$ When a trust scheme is imposed, the non-performance of the trust obligation is actionable. Furthermore, a trust claimant need not necessarily be entitled to a lien at the time at which the trust claim is advanced. ${ }^{18}$

In Alberta the adoption of comprehensive trust provisions was considered and rejected in 1967 by retired Chief Judge Nelles V. Buchanan who had been commissioned to inquire into the adequacy of the provisions of The Mechanics' Lien Act as it was then (the Buchanan report). ${ }^{19}$ The reasons as outlined in his Report may be summarized as follows:

1. The trust clauses have little or no significance for the large and generously financed corporations, whether contractors or subcontractors. They keep excellent records; for each contract separate accounts are maintained and funds from various jobs are either not intermingled or can readily be accounted for. With adequate funds at their disposal there is no need or temptation to apply contract funds to any purpose forbidden by the trust clause;

2. The presence of the trust clause in the Act is a threat, and possibly a deterrent to the misapplication of funds, only to the underfinanced or to the dishonest; and

3. The assignment of contract funds has long been the choice security used by contractors in securing interim financing from banks, pending the receipt of draws from lenders secured by mortgage. The imposition of a trust has an undesirable effect on the flow of credit.

Builders' lien legislation was once again reviewed in Alberta in the early 1980s culminating in the Builders' Lien Amendment Act 1985. ${ }^{20}$ The amendments introduced a limited trust concept imposing a trust on monies paid to a contractor or subcontractor after the issuance of a Certificate of Substantial Performance. In reality the present trust provisions affect a small portion of the contract price as a Certificate of Substantial Performance is usually not issued until the contract is $97 \%$ complete. The trust then operates on the $3 \%$ or less of the work value which has yet to be paid for and on the holdback for the work done, which may be as little as $15 \%$ of the $97 \%$ value. Further, if a Certificate of Substantial Performance is not issued for a project, none of the contract money is trust money. Finally, the trust does not extend to the owner. The present trust concept in Alberta is, therefore, very limited.

17. See Northern Eau Claire Construction Materials v. Pruett et al. 83 A.R. 155, 57 Alta. L.R. (2d) 140 (Q.B.) and County of St. Paul, No. 19 v. Genereux Workshop (Bonnyville) Ldd. et al. (1984) 55 A.R. 9, 32 Alta. L.R. (2d) 395, 8 C.L.R. 148 (C.A.).

18. Minneapolis-Honeywell Regulator Co. Lid. v. Empire Brass Manufacturing Co. Ldd. supra n.6, per Locke J. at p. 703 S.C.R.

19. Public Inquiry into the Adequacies of the Provisions of the Mechanics' Lien Act, 1960, Report of the Commissioner, His Honour Chief Judge Nelles V. Buchanan (Retired), November 1967.

20. S.A. 1985 , c. 14 . 


\section{PROPOSALS FOR REFORM}

\section{A. BRITISH COLUMBIA}

In 1972 the Law Reform Commission of British Columbia issued its report on builders' liens. ${ }^{21}$ In dealing with the trust provisions contained in the B.C. Mechanics' Lien Act, the Commission first considered whether or not the trust provisions should be retained. It stated that it had "discovered no evidence to suggest that the existence of a trust is increasing the difficulties of contractors and subcontractors in obtaining credit facilities from lending institutions." 22 Also, it did "not appear to cause any additional slowing down of the flow of funds along the construction chain." 23 The Commission therefore recommended the retention of the trust provisions with a few modifications.

The modifications proposed included amendment to make it clear that the trust operated even in the situation where the time limited for filing a lien had expired. Also, although it was clear that the B.C. Act does not make an owner a trustee, it was recommended that the necessary amendments be implemented so as to make it clear that moneys owing to a contractor or subcontractor which would, if paid to the contractor or subcontractor, become trust moneys should not be subject to attachment under the Attachment of Debts Act, R.S.B.C. 1960, c.20. Such would eliminate the problem encountered in cases such as Castelein v. Boux ${ }^{24}$ and Mike's Roofing \& Insulation Ltd. v. Horden ${ }^{25}$ where it was held that moneys owed to a contractor by an owner who was garnisheed by a judgment creditor of the contractor were not trust moneys and the plaintiff, the judgment creditor of the contractor, was entitled to same. The Commission felt that such a result was inconsistent with the policy of the trust provision as it gave the judgment creditor a better right against the owner/garnishee than he would have against the contractor who was indebted to him.

\section{B. MANITOBA}

Manitoba also flirted with the idea of removing the trust provisions from its builders' lien legislation. The Manitoba Law Reform Commission in its 1979 Report ${ }^{26}$ pointed out that the then current fines and penalties for breach of trust were ridiculously low and prosecutions were rarely undertaken either pursuant to provincial legislation or the Criminal Code. In addition, it was suspected that the provisions made banks and other lending institutions reluctant to provide normal financing arrangements within the construction industry. The Commission acknowledged that it had found, however, no evidence of any impediment to financing and indeed found general favour for the trust scheme within the construction industry. As a result, its recommendations included retention of trust provisions

21. Law Reform Commission of British Columbia, Report on Debtor-Creditor Relationships, Part II Mechanics' Lien Act: Improvements on Land, 1972.

22. Id. p. 91.

23. Id. p. 92.

24. (1943) 3 D.L.R. 357 (Man. C.A.).

25. (1965) 46 D.L.R. (2d) 595 (B.C. Co. Ct.).

26. Manitoba Law Reform Commission, Report on Mechanics' Lien Legislation in Manitoba, 1979. 
along with more stringent enforcement provisions and minimum accounting standards. The Commission considered briefly the idea of licensing all builders in Manitoba, but concluded that such an extreme step was not warranted at the time.

\section{ONTARIO}

The Province of Ontario undertook its most recent reform of its builders' lien legislation in the early 1980s. A draft of an entirely new Act was circulated in early 1981 with an accompanying Discussion Paper by the Ministry of the Attorney General which then established an Advisory Committee on the Draft Construction Lien Act. The Advisory Committee issued its report in April 198227 and recommended that the trust concept be retained, but clarified. Specifically, the Committee recommended that the new Act specify the obligations of a trustee and outline exactly how those obligations were to be discharged. It also recommended that the Act provide for application to the Court for directions with respect to the rights and obligations of all parties interested in the trust.

\section{SASKATCHEWAN}

Following the example of Ontario, Saskatchewan undertook a further review of its builders' lien legislation in 1983. In the Report by the Special Advisory Committee to the Minister of Justice on Builders' Liens released in August 1984 ${ }^{28}$, the Committee recommended the following with respect to the trust provisions in the existing Act:

1. the Act should clearly indicate that there must be privity of contract between a trustee and his beneficiary;

2. there should be no trust for the payer of trust moneys;

3. the trust should terminate upon payment to the beneficiary;

4. the Act should clearly constitute a trust in the owner's hands of money borrowed for a project or, in the case of the Crown or where the owner receives money otherwise than through borrowing, when the moneys are due and payable under the contract;

5. the Workers' Compensation Board should not be constituted a trust beneficiary;

6. the proceeds of the sale of improved property should constitute a trust fund in the owner's hands less reasonable costs of sale and amounts necessary to discharge any pre-existing indebtedness until the contractor is paid;

7. there should be no requirement imposed by the legislation upon the trustee as to how he should distribute the funds; and

8. a trustee should be able to set off, as against his beneficiary, debts, claims, or damages incurred with respect to the improvements as to all amounts in his hands up to but not including the holdback.

The Committee also made extensive recommendations with respect to the priorities between trust beneficiaries and third parties with claims against the trustee.

27. Report of the Attomey General's Advisory Committee on the Draft Construction Lien Act (Ontario 1982).

28. "Liens in the Construction Industry", A Report Prepared for the Honourable J. Gary Lane, Q.C., Minister of Justice by the Special Advisory Committee on Builders' Liens (Saskatchewan 1984). 


\section{RECOMMENDATIONS OF THE TASK FORCE}

In Alberta the Joint Government/Industry Task Force on Builders' Liens was established in June 1987 with a mandate to review the existing legislation, consider the views of interested persons and groups, consider alternatives to the Builders' Lien Act and prepare draft legislation based on its recommendations. The Task Force is comprised of the representatives of a number of associations which have a direct interest in builders' lien legislation. These associations include the Alberta Construction Association, Mortgage Loans Association of Alberta, Alberta and NWT (District of Mackenzie) Building and Construction Trades Council, Alberta Home Builders' Association, Urban Development Institute Alberta and Building Owners and Managers Association. The Task Force released its Preliminary Report in September 1988. ${ }^{29}$ The stated primary objective of the Task Force was to create a legislative framework which would provide greater assurance of payment for everyone in the construction industry. ${ }^{30}$ With this objective in mind, the Task Force recommended a number of substantial changes to the existing legislation, including registration of contractors and subcontractors, elimination of the statutory holdback, the adoption of comprehensive trust provisions similar to those in Saskatchewan and Ontario and the creation of a new remedy for pursuing trust funds called the "Stop Notice". This paper will focus on the proposed trust provisions, however, a complete discussion is not possible without reference to the "Stop Notice", elimination of the statutory holdback, and registration.

The recommendations of the Task Force with respect to the adoption of trust provisions may be summarized as follows:

1. There should be a comprehensive trust scheme similar to that in Saskatchewan and Ontario, i.e. all moneys received on account of the contract price for the improvement are held in trust for the benefit of those with whom the trustee has contractual privity. The trustee's obligations should be discharged only when he has satisfied all his outstanding accounts, or when there is no more trust money;

2. The owner should be a trustee with respect to:

(a) funds secured by a mortgage, or other security, advanced to or on behalf of the owner for the purpose of financing the improvement;

(b) any funds in the hands of the owner, or received by the owner, for payment of the improvement,

(c) any funds, or source of funds, identified by the owner to the contractor as being funds earmarked for paying the cost of the improvement;

(d) any revenue generated from the improved land subject to prior encumbrances;

(e) any funds derived from the sale of the improvement, subject to normal expenses and prior encumbrances; and

(f) net proceeds of insurance should the improvement be damaged or destroyed.

29. Supra n.1.

30. The Task Force also dealt with the oil and gas industry, however, the scope of this paper will be limited to the construction industry. 
3. All contractors or subcontractors who are in receipt of trust funds should be required to deposit such funds in a separate consolidated trust account maintained in Alberta. It was recommended that owners, however, not be required to maintain a separate trust account.

4. One special remedy to pursue trust funds would be the Stop Notice, while the remedy to pursue the land would continue to be the lien. Conventional remedies to enforce trusts, as well as the attachment of "lien funds", would also be available in the appropriate circumstances. Each remedy should be distinct and could be pursued separately or together. It was recommended, however, that a person should be entitled to a trust claim only if he were at some time entitled to a lien.

5. If a contractor or subcontractor used his own funds, or borrowed funds, to pay trust obligations, a sum equal to that paid to trust beneficiaries would not constitute trust funds (or in other words the trustee could reimburse himself or repay the lender from funds which would otherwise be trust funds).

6. A trustee should be able to set off against trust funds any counterclaim against a beneficiary which has arisen out of the project.

7. The trustee's obligation would terminate upon payment of all trust funds to beneficiaries. If a contractor or subcontractor has underbid a project so that the claims of his beneficiaries exceed the trust funds he will receive, nevertheless, he would discharge his trust obligations if he pays the trust funds to his beneficiaries.

8. A provincial offence would be created for breach of the statutory trust with significant fines in order to serve as a deterrent.

9. The new legislation would expressly pierce the corporate veil and create personal civil liability for directors and officers who participated or acquiesced in a breach of trust by a corporation.

The proposals of the Task Force with respect to trust provisions significantly differ from similar legislation in other provinces in two ways. The first is the Task Force's proposal to compel a trustee to maintain a separate trust account. The Task Force envisions this as a consolidated account, that is, the trustee need not maintain a separate account for each project. However trust funds are not to be commingled with a trustee's own funds. This simple requirement will effectively eliminate a problem encountered in other provinces where a contractor pays trust money into his general account and his bank takes the money to cover the contractor's previous indebtedness to the bank. As long as the bank did not have notice, actual or constructive, that the funds were subject to a trust, the bank is entitled to the moneys. ${ }^{31}$ Presumably this cannot readily occur if a separate trust account is maintained, unless of course the trustee does not deposit the funds in the trust account.

The second major difference is the concept of the Stop Notice. The Stop Notice would be essentially a new remedy which would permit a trust beneficiary to pursue trust funds in the hands of the owner. The scheme envisioned by the Task Force is that the Stop Notice will be a document served on the owner (as opposed to an encumbrance registered against the owner's land) by an unpaid beneficiary other

31. For more in depth discussion, see below. 
than the contractor. When an owner has been served with a Stop Notice he must reply to the serving party within ten days indicating one of three things,

1) he has set aside trust money in the amount claimed in the Stop Notice,

2) trust money has not been set aside, but will be set aside from a source which constitutes trust funds when such funds are received by the owner, or

3) no money has been set aside nor will it be set aside and the reason for same, for example, the owner has paid the contractor in full.

Once served with a Stop Notice the owner then becomes trustee of the amount claimed in the Stop Notice for the benefit of the party serving the Stop Notice. This serves as an exception to the general rule that contractual privity is necessary for the trustee/beneficiary relationship within the scheme. After the party serving the Stop Notice has received a reply from the owner, the onus will then be on that party to commence an action against his immediate trustee (the party immediately above him in the chain from whom he has not received payment). The owner would be served with a copy of the Statement of Claim and must then pay into court to the credit of the said action the funds previously set aside. If the party who served the Stop Notice does not commence an action and serve a copy of the Statement of Claim on the owner within the set time period (120 days from service of the Stop Notice has been suggested) the Stop Notice will lapse and the owner may pay the amount set aside to the contractor with impunity.

The proposals of the Task Force are also unique in their recommendation of registration and elimination of the statutory holdback. The "holdback" refers to the statutory obligation of the owner in Alberta to withhold $15 \%$ of the value of the work done and materials furnished when making a payment to the contractor. If liens are registered on the owner's title, the owner is able to clear his title by paying into court the lien fund which is comprised of the $15 \%$ holdback and the amount then payable but unpaid, if any, under the contract over and above the $15 \%$. Therefore, as long as the owner complies with the holdback requirement, he will never be liable for more than the contract price. The amount payable but unpaid under the contract is subject to any right of counterclaim or set-off between the owner and contractor. The holdback, however, is not subject to set-off. ${ }^{32}$ Accordingly, in a situation where the contractor or subcontractor abandons the contract or the job is deficient, lien claimants often only have recourse to the holdback.

The Task Force considered the problems with the holdback, namely that it provides very limited security to lien claimants and that it causes cash flow problems for contractors and subcontractors who must finance the difference between what is received and what must be paid for labour, materials and overhead. It concluded that with the trust provisions and Stop Notice remedy, the increased cash flow would be of greater benefit to those near the end of the project, such as the landscaper, than was the limited security of the holdback.

With respect to registration, the Task Force was of the opinion that it was warranted for two reasons. One, it would help eliminate unscrupulous contractors and subcontractors and two, the trust provisions and consolidated trust account would be effective only if contractors and subcontractors understood their obligations as

32. See Re Mechanics' Lien Act, Horowitz v. Rigoux Building Enterprises Lsd. et al. (1960) 32 W.W.R. 540 (Alta. S.C., App. D.) and Community Capital Management (1976) Ld. v. Master Mechanical Plumbing and Heating Ld. et al. (1982) 17 Alta. L.R. 10 (C.A.). 
trustees. The Task Force accordingly recommended that applicants be required to pass a simple test in order to be registered initially, that registration be renewed on an annual basis and that contractors and subcontractors be required to post a $\$ 25,000$ bond. A dishonest contractor or subcontractor would face revocation or nonrenewal of his registration and also would be unlikely to obtain the necessary bonding. Anyone who operated without being registered would not only be unable to claim the benefit of the Act, but would also be unable to enforce his contract. Lastly, the Task Force recommended that registration be required only for those contractors and subcontractors who, in the normal course of business, handle trust funds. This would effectively exclude the person who wished to act as his own contractor when building his home, the neighborhood handyman and most suppliers.

\section{THE NATURE OF THE STATUTORY TRUST}

\section{A. A TRUST CREATED BY STATUTE}

\section{A trust has been defined $a^{33}$,}

the relationship which arises whenever a person called the trustee is compelled in equity to hold property, whether real or personal, and whether by legal or equitable title, for the benefit of some persons (of whom he may be one, and who are termed beneficiaries) or for some object permitted by law, in such a way that the real benefit of the property accrues, not to the trustees, but to the beneficiaries or other projects of the trust".

In order for a trust to arise three characteristics must be present, namely: 1) certainty of intent to create a trust, 2) certainty of the subject matter of the trust and, 3 ) certainty of the objects or beneficiaries.$^{34}$ A statutory trust is simply a trust relationship created by statute. Mr. Justice Meredith in B.C. (Govt.) v. Henfrey Samson Belair Ltd. defined a statutory trust as follows, "A statute creates a trust when the language vests ownership to an asset in someone other than the holder . . . . A trust created by statute will be effective to vest title so that the asset deemed to comprise the trust property does not form part of the property of the holder. And if the holder is bankrupt, the asset does not form part of his estate. "35 As for whether or not the creation of a statutory trust is within the legislative competence of a province, the Supreme Court of Canada made it clear in John M.M. Troup Ltd. et al. v. Royal Bank of Canada ${ }^{36}$ that provinces may legislate in furtherance of a social policy scheme to protect certain interests through the means of a statutory trust such as the trust provisions in the builders' lien legislation. As to whether or not such a statutory trust was enforceable in bankruptcy, Mr. Justice Judson stated the following, "As to bankruptcy, the creation of the trust by s.3(1) [of the Ontario Act] does affect the amount of property divisible among the creditors but so does any other trust validly created." ${ }^{37}$

Although a trust may be created by statute, it must still meet the basic requirements of a trust, namely the requirements of certainty. In the area of builders' lien

33. Waters, Law of Trusts in Canada, supra n.7 at p. 5.

34. Id. at p. 107.

35. 5 B.C.L.R. (2d) 212, rev'd for other reasons (1987) 40 D.L.R. (4th) 729 , 13 B.C.L.R. (2d) 346 (C.A.) (leave to appeal to the S.C.C. granted Dec. 18/87, Bull. of S.C.C. Proceedings @ 2046).

36. [1962] S.C.R. 487, 3 C.B.R. (N.S.) 224, 34 D.L.R. (2d) 556 (see case comment by W.C. Graham at (1963) 21 U. T. Fac. L.R. 135).

37. Id. at D.L.R. p. 572. 
trusts, certainty of intent is not a problem as it is clear from the legislation itself. Depending on the exact words of the particular statute, certainty of objects is usually not a concern in builders' lien trusts either. For example, the Ontario legislation defines the objects or beneficiaries of the trust as follows, "the subcontractors and other persons who have supplied services or materials to the improvement who are owed amounts by the contractor. ${ }^{38}$ While there are some cases dealing with the definition of subcontractor and materialmen, for the most part the contractor/trustee is well aware of the identity of the beneficiaries to whom he owes a duty. ${ }^{39}$

As for certainty of subject matter, again the various builders' lien statutes are quite clear. In Ontario the subject matter of the contractor's and subcontractor's trust is defined as "All amounts (a) owing to a contractor or subcontractor, whether or not due or payable; or (b) received by a contractor or subcontractor, on account of the contract or subcontract price of an improvement constitute a trust fund . . ." ${ }^{40}$ While there have been a number of cases dealing with the definition of "received" and the determination of the amount owing to the contractor or subcontractor, ${ }^{41}$ certainty of subject matter of builders' lien trusts has not been a matter of concern.

There has been some controversy recently with respect to the certainty of subject matter in some statutory trusts. The issue was raised by Mr. Justice O'Sullivan of the Manitoba Court of Appeal in Robinson, Little and Co. Ltd. v. Manitoba. ${ }^{42}$ The situation involved the Manitoba Payment of Wages Act which stated that every employer was deemed to hold wages due or accruing due to an employee in trust for the employee. Mr. Justice O'Sullivan expressed doubt that the provision created a valid trust as the trust property was a debt and " $(y)$ ou cannot have a trust of a debt. You can only have a trust of an asset." ${ }^{43}$ The controversy would appear to be limited to so-called deemed trusts, however, as Mr. Justice O'Sullivan recognized that a province is capable of creating a valid statutory trust and even used the trusts established under builders' lien regulations as an example of a valid statutory trust which is effective to remove the trust property from the estate of a bankrupt trustee as contemplated by s.47(a) of the Bankruptcy Act. ${ }^{44}$

38. Construction Lien Act, S.O. 1983, c.6, s.8.

39. See Hansen v. C.N.R. [1983] 4 W.W.R. 23, 23 R.P.R. 83 (Sask. C.A.), Re Terra Cotta Contracting Co. [1964] 1 O.R. 661 (S.C.), Re Northwest Electric Lid. [1973] 3 W.W.R. 156 (B.C.S.C.), Clarkson Co. v. Ah-No-Kee-Win Ventures Ld. (1983) 45 C.B.R. (N.S.) 253, Re Schulz Concrete Pipe Ldd. (1979) 32 C.B.R. (N.S.) 157 (Ont. S.C.) and Re Thomas Electric Co. (1981) 37 C.B.R. (N.S.) 7 (Ont. S.C.).

40. Supra n.35.

41. For consideration of the word "received" see Minneapolis-Honeywell Regulator Co. v. Empire Brass Co. supra n.6, Royal Bank v. Wilson (1963) 39 D.L.R. (2d) 36, 42 W.W.R. 1 (Man. C.A.), A \& M Printing Contractors Lid. v. Byers Construction Western Ldd. (1981) 122 D.L.R. (3d) 355 (B.C.C.A.), Modular Products Lid. v. Aristocratic Plywoods Led.; Modular Products Lid. v. R. [1974] 2 W.W.R. 90 (B.C.C.A.), Westem Caissons (Sask.) Ld. v. Buildall Const. Lid. (1978) 81 D.L.R. (3d) 664, affm'd [1978] 5 W.W.R. 765 (Sask. C.A.).

For a discussion of determination of the amount owing to the contractor or subcontractor, see "SetOff' below.

42. [1986] 6 W.W.R. 655, 61 C.B.R. (N.S.) 221, 31 D.L.R. (4th) 701 (sub nom. Clarkson Gordon Inc. v. Man.).

43. Id. D.L.R. p. 658.

44. Id. p. 657. See also the decision of Macfarlane J.A. in B.C. (Gov't) v. Henfrey Samson Belair Lid., supra n.35 at p. 354 B.C.L.R. 


\section{B. DUTIES OF A BUILDERS' LIEN TRUSTEE}

A statutory trust is still basically a trust and as pointed out by Mr. Justice Martland in John M.M. Troup Ltd. v. Royal Bank of Canada , "(a)lthough the trust is created by statute, it thereupon becomes subject to the application of the rules of equity". ${ }^{45}$ We will see that this means that the rules of equity apply unless they have been specifically displaced by the very terms of the statute or, in the opinion of the court, by necessary implication..$^{46}$

The trust found in present builders' lien legislation is what is commonly referred to as a "bare trust". ${ }^{47}$ In other words, the legislation indicates that the trustee has no active duties to perform other than paying over the trust moneys to the beneficiaries. This does not mean however that the trustee has no obligations with respect to the beneficiaries. As long as the trustee holds trust property, he has certain basic duties such as to preserve the property and to avoid conflict between his own interests and those of the beneficiaries. Over the years the courts have refined the duties of the builders' lien trustee. At this point it would be useful to review each duty separately as defined by the courts.

i) Duty to Preserve Trust Assets

The duty which has been the subject of the most litigation, although in a roundabout way, is the duty of the trustee to protect trust assets. As evidenced by the multitude of cases, ${ }^{48}$ the most common situation involving builders' lien trusts is where the trustee, usually the contractor, receives money on account of the construction contract, which is impressed with a trust in favour of unpaid subcontractors and suppliers, and the contractor pays the trust funds into his general operating account at his bank rather than establishing a separate trust account. The contractor is usually indebted to the bank at which he maintains this general account and problems arise when the bank "scoops" the trust money and applies it to the prior indebtedness of the contractor. At that point the trustee, the contractor, is usually insolvent and the beneficiaries' only hope of recovering any money is to go after the bank. Most of the reported cases deal with the issue of whether or not the bank was aware of the nature of the funds and thereby participated in a breach of trust making it liable to the trust beneficiaries. Whether or not the beneficiaries are successful against the bank,

45. Supra n.36 at p. 567.

46. See Albern Mechanical Limited and Connie Steel Products Limired v. T.D. Bank and Mariani, Cascone and Serafino Lid. (1979) 32 C.B.R. (N.S.) 173 at 176.

47. See Waters, Law of Trusts in Canada supra n.7 at p. 27.

48. See Minneapolis-Honeywell Regulator Co. v. Empire Brass Co. supra n.6, Standard Electric Co. Ld. v. Royal Bank of Canada and Stewart (1960) 1 C.B.R. (N.S.) 64 (Ont. S.C.), Pilkington Glass Ldd. v. Canadian Imperial Bank of Commerce (1964) 6 C.B.R. (N.S.) 261 (B.C.S.C.), Ross v. Royal Bank of Canada (1965) 8 C.B.R. (N.S.) 303 (Ont. S.C.), Re John Rischie; The Clarkson Co. Ld. v. C.I.B.C. et al. [1966] S.C.R. 513, 8 C.B.R. (N.S.) 280, 57 D.L.R. (2d) 193 (see case comment by J.T. Kennish at (1964) 3:116 Osgoode Hall L.J. 116), Horsman Bros. Holdings Lid. et al. v. Dahl et al. (1981) 20 R.P.R. 208 (B.C.S.C.), Perlmutter Shore Ld. v. Bank of Montreal (1982) 40 C.B.R. (N.S.) 1 (Ont. S.C.), Trilec Installations Ldd. v. Bastion Construction Led. et al. (1982) 135 D.L.R. (3d) 766 (B.C.C.A.), Overhead Door Company of Regina (1973) Lid. v. SEDCO et al. (1985) 37 Sask. R. 313 (Q.B.), Henry Electric Lid. et al. v. Farwell (1986) 5 B.C.L.R. (2d) 273 (B.C.C.A.), Heating Engineering Installations (1981) Ldd. et al. v. Raymond Contracting Ltd. et al. (1986) 56 Sask. R. 119 (Q.B.), Grinnell Fire Protection Systems Co. Lid. v. Bank of Montreal (1986) 21 C.L.R. 44 (B.C.S.C.), and Emco Supply, A Division of Emco Lid. v. Guegen et al. (1987) 25 C.L.R. 229 (Ont. S.C.). 
it is clear that the contractor is in breach of the trust. In the situation of a corporate trustee, officers and directors will be personally liable as well where it is shown that they were the operating mind of the corporate trustee.

The clearest statement of the duty to protect the trust assets was made by the British Columbia Court of Appeal in Trilec Installations Ltd. v. Bastion Construction Ltd. et al. where Mr. Justice Carrothers stated that " it is clear that the individual appellant committed a breach of trust by failing to preserve the trust moneys for the trust beneficiaries including the corporate appellant by depositing the same for general purposes of the corporate appellant which was the trustee of these funds." ${ }^{49}$ It is difficult to imagine how a trustee can fulfil this duty without segregating trust moneys in a separate account. Yet to date the trust provisions in the various builders' lien statutes contain no such requirement and the general practice in the industry is to not segregate trust funds, although most large contractors maintain detailed accounts with respect to each project. The proposal of the Task Force to require that trustees maintain a trust account must be seen as a step in the right direction. Although it may be argued that the Task Force is simply recommending codification of the common law, it appears that contractors and other builders' lien trustees require a reminder of their duty to segregate and protect trust assets. In fact, the Task Force recommendation is more permissive than the common law requirement in that it would permit a consolidated trust account rather than requiring a separate trust account for each contract. ${ }^{50}$

ii) Distribution of Trust Funds

Substantial litigation has also arisen with respect to the obligations of the builders' lien trustee in distributing trust funds to the beneficiaries. The present builders' lien statutes provide no direction with respect to distribution and one would assume, therefore, that since a discretion is not expressly conferred, the duty of the trustee is to maintain an even hand among the beneficiaries. ${ }^{51}$ The Supreme Court of Canada determined that this was not the case, however, in Minneapolis-Honeywell Regulator Co. Ltd. v. Empire Brass Manufacturing Co. Ltd. Mr. Justice Rand, speaking for the majority, stated that "Section 19 (of the B.C. Mechanics Lien Act) does not, however, require that [the trust moneys] be distributed on a pro rata basis. The subcontractor has, in this respect, a discretionary power, and his obligation is satisfied when the trust moneys are paid out to persons entitled, whatever the division." ${ }_{52}$ Such a discretion is certainly not expressly set out in the statute, but may be implied by the nature of the construction industry. As explained by Mr. Justice Smily of the Ontario Supreme Court in Re Putherbough Construction Company Limited, ${ }^{53}$

.. . it would be impractical to require the contractor to pay the proceeds of the contract rateably to the beneficiaries mentioned and specified ... . during the ondinary course of construction ... a contractor makes payments to creditors in the ordinary course of business and naturally he could not be expected to be called to account for those payments in the case of

49. Supra $\mathbf{n} .48$ at p. 768.

50. Also see Bank of Nova Scotia v. Societe General (Canada) et al. (1988) 68 C.B.R. (N.S.) 1, 58 Alta. L.R. (2d) 193, 87 A.R. 133 (C.A.) where it was held that the commingling of trust funds does not destroy a trust.

51. See Waters, Law of Trusts in Canada supra n.7 at p. 787.

52. Supra n.6 at D.L.R. p. 563.

53. (1958) 37 C.B.R. 6 at p. 9. 
a later deficiency nor could the creditors who were entitled to receive payment, that is who are beneficiaries of the fund, be expected to retum such payments. Business could not be carried on in such uncertainty as requirements of that nature would entail or create.

This means that contractors must be able to pay their subcontractors and suppliers as the work proceeds and not be in breach of the trust even if some beneficiaries end up not being paid in full. As long as the contractor has paid out all the trust funds to trust beneficiaries, he will have discharged his trust obligations. The alternative would be for the contractor to withhold payment from all beneficiaries until the end of construction when he could be sure of ascertaining all the beneficiaries and their pro rata portion. This would be a commercially unacceptable impediment to the flow of funds and, one would assume, contrary to the intent of the legislation.

This principle, first enunciated by Mr. Justice Rand in Minneapolis-Honeywell, has since been refined. Mr. Justice Smily in Re Putherbough Construction went on to say that while the contractor may not be obliged to pay rateably during the ordinary course of construction, where the contractor/trustee is bankrupt and there is going to be a deficiency of trust funds, the trustee in bankruptcy must distribute funds rateably among creditors and without regard to an assignment given to one of the creditors intending to favour that creditor over others. Mr. Justice Smily's comments were approved by the Ontario Court of Appeal in the decision of Guaranty Trust Company of Canada v. Beaumont ${ }^{54}$ In that case the insolvent contractor/trustee had abandoned the contract and assigned the remaining proceeds of the contract to a group of creditors who were beneficiaries of the contractor's trust. The group did not include all the beneficiaries, however, and the Court determined that in the situation of an insolvency such as that, all beneficiaries must be included and receive equal treatment.

During the ordinary course of events, not only is the contractor/trustee not obliged to maintain an even hand among the beneficiaries, but also he may choose to favour himself over his beneficiaries. The trust schemes currently in place all contain a provision permitting a trustee to reimburse himself or a lender when the trustee or the lender provides funds to pay beneficiaries and such does not constitute an unlawful appropriation or conversion of trust funds to the use of the trustee. The Supreme Court of Canada in Re John Ritchie Limited; The Clarkson Company Limited v. The Canadian Bank of Commerce et al. ${ }^{55}$ recognized early on that since the Ontario trust provisions did not contain any direction as to the manner in which the trust fund is to be apportioned among those entitled, there was nothing to prevent the contractor/trustee from preferring himself by retaining sufficient funds out of the trust moneys to reimburse himself for sums paid to beneficiaries even though there proved to be insufficient funds to pay all the beneficiaries. It is interesting to note that in this case the argument that the contractor/trustee was entitled to prefer itself was being advanced by the contractor's bank which had "scooped" trust funds out of the contractor's general bank account to cover a loan granted by the bank to the contractor, the proceeds of which were used to pay the contractor's creditors/beneficiaries. The Supreme Court agreed that although the contractor was entitled to this privilege, it could be exercised only by the contractor itself and not by the bank purporting to act on behalf of the contractor. As stated

54. (1967) 61 D.L.R. (2d) 286.

55. Supra n.48. 
by Mr. Justice Cartwright, "It is elementary that a trustee cannot delegate the exercise of a discretion committed to him by the instrument creating the trust and a fortiori he cannot be compelled by a creditor who is a stranger to the trust to exercise his discretion in a particular manner which will benefit that stranger to the detriment of the beneficiaries." $\$ 6$

Although the results may seem unfair at times, it does appear that business efficacy dictates that the contractor/trustee must have a discretion with respect to the payment of trust funds. It is interesting to note that when Saskatchewan first included trust provisions in its Mechanics' Lien Act in 1973, it directed that the builder, contractor or subcontractor distribute trust money among the beneficiaries of the trust " according to the liabilities of the builder, contractor or subcontractor to such persons, on a pro rata basis" ${ }^{57}$ This provision met with criticism in the Report by the Special Advisory Committee to the Minister of Justice on Builders' Liens ${ }^{58}$ which pointed out that the requirement of pro rata distribution posed such practical problems that it had not been adopted by Ontario in its legislation. The Advisory Committee's recommendation that the direction with respect to distribution of the trust fund be eliminated was adopted in the present legislation in Saskatchewan.

\section{SET-OFF}

A further departure from the general law of trusts is found in the express provisions permitting a trustee to set off against trust funds any counterclaim he may have against a particular beneficiary. The builders' lien statutes of Saskatchewan, Ontario and Manitoba contain such a provision, although each is distinctive. The Saskatchewan Act provides that a trustee may set off against trust funds as between himself and a beneficiary, an amount "equal to the balance in the trustee's favour of all outstanding debts, claims or damages, that are related to the improvement." 59

The Manitoba Act is unique in that it makes the owner a beneficiary of the contractor's trust to the extent that the owner has any right of set-off or counterclaim relating to the performance of the contractor's contract. ${ }^{60}$ Similarly, the contractor is a beneficiary of the subcontractor's trust and so on down the chain. There is no discussion in the Manitoba Law Reform Commission's report ${ }^{61}$ which would explain why this tactic was thought necessary. One explanation is that it would eliminate the possibility of trust beneficiaries claiming priority over the right to set off on the basis that the trust corpus was established prior to the right of counterclaim arising.

The Ontario Act is unique in that it does not restrict the right of set-off to claims arising in relation to the improvement. Claims arising out of other projects may be set off. The Ontario provision is discussed in greater detail below.

56. Id. C.B.R. (N.S.) p. 291. See also Overhead Door Company of Regina (1973) Lid. v. SEDCO et al. supra n.48.

57. Supra n. 14 s.5(2).

58. Supra n.28.

59. Builders' Lien Act, S.S. 1984-85-86, c.B-7.1, s.13.

60. Builders' Liens Act, S.M. 1980-81, c.7, s.4(1).

61. Supra n.26. 
In British Columbia, which does not specifically provide for set-off, it has been held that the trust imposed on the contractor attaches only to the net amount owed by the owner to the contractor. ${ }^{62}$ Accordingly the owner is permitted to set off against the contractor without any interference with trust funds. This rationale only works where the trust does not arise until the funds have been received by the contractor or subcontractor. In those provinces where a trust attaches to funds in the hands of the owner and the right of set-off has been adopted, it may be preferable to specify, as has Manitoba, that the right of set-off enjoys the same or greater status than trust claims or that the owner has the right to set off against what would otherwise be trust funds as has Ontario.

The right to set off goes beyond the provisions permitting a trustee to reimburse himself from trust funds for sums paid out of his own pocket or to repay a lender when the borrowed funds were used to pay trust beneficiaries. These provisions do not serve to reduce the funds flowing down the chain. If one envisions the value of the entire contract as a bank account, then the reimbursement provisions mean that there is no withdrawal for which there has not been a corresponding deposit. Frequently situations arise, however, where the contractor or subcontractor abandons the contract, often because they are bankrupt, or otherwise fail to perform. The resulting cost of completion or damages resulting from delayed completion thereby increase the cost of the project to the owner. The set-off of these increased costs against the amount owing to the contractor or subcontractor serves to decrease the funds flowing down the construction chain to the detriment of those below the defaulting party. The Ontario Court of Appeal in Len Ariss \& Co. v. Peloso $0^{63}$ outlined the scope of set-off when it specified that the owner was entitled to deduct from the contract price the costs of completion, any outstanding accounts in favour of the owner as between the owner and contractor, any damages awarded to the owner for delays in completion, and past payments made to the contractor.

The subject of set-off raises a fundamental issue, namely who is to be protected by builders' lien legislation. In the situation where there is a deficiency the question arises as to who is to bear the loss. Where it is the contractor who has defaulted, it will either be the owner if he must pay in full for the work done, or it will be the subcontractors, suppliers and labourers if the owner is permitted to set off his damages against the amount owing to the owner. Given the numerous judicial statements that builders' lien legislation is to protect the subcontractors, materialmen and labourers, one might expect that their interests would prevail. It has been a long standing principle, expressly stated in most builders' lien statutes, however, that the liability of the owner is never more than the contract price (assuming the owner has complied with the statutory holdback provisions, if any). ${ }^{64}$ This leads to conflict. Lyon, Co.Ct.J. in Standard Industries Ltd. v. Treasury Trails Holdings Ltd. , after quoting the Ontario Court of Appeal in S.I. Guttman Ltd. v. James D. Mokry

62. United Metal Fabricators Ld. v. Voth Bros. Const. (1974) Ldd. et al. (1987) 42 D.L.R. (4th) 193 (B.C.C.A.).

A similar result would likely occur in New Brunswick as indicated in Saimt John Tile and Terrazzo Co. Lid. v. Harding Carpets (1988) 68 C.B.R. (N.S.) 196, 31 C.L.R. 135 (N.B.C.A.). See also T.M. Collins, "An Argument Against the Owner's Right of Set Off Under the Mechanics' Lien Act" (1986) 35 U.N.B. Law J. 211.

63. [1958] 1 O.R. 643, 13 D.L.R. (2d) 178.

64. The relevant provision in Alberta is Builders' Lien Act, R.S.A. 1980, c.B-12, s.16.4. 
$L t d .{ }^{65}$ and Freedman v. Guaranty Trust Co ${ }^{66}$ stated " . . I t take it that the interpretation should be given to the section which results from a strict construction in the sense of protecting the claims of those who supply work and materials so long as the owner is not prejudiced." 67 On the other hand, there is the strong dissent of Laskin J.A., as he then was, in S.I. Guttman Ltd. v. James D. Mokry Ltd ${ }^{68}$ where in determining that the owner's right of set-off could not be used to deny payment to an unpaid subcontractor, he stated at page 21 (O.R.) that:

It is my view that so far as an innocent subcontractor lien claimant is concemed, the relations of the owner and the contractor inter se are res inter alios acta. The owner is, of course, also innocent in the circumstances of an abandonment of the work by the contractor, but his choice of a contractor should not be a risk assumed by a subcontractor whose right to a lien is original under the Act and not derivative. It is one thing to say that nothing is owing to the contractor by the owner as a result of the abandonment; it is another thing to say that the value of the work done for the owner should be offset against a subcontractor by the owner's cross-claim against the contractor.

There is also the statement of Killeen, Co.Ct.J. in Bre-Aar Excavating Ltd. v. D'Angela Construction (Ontario) Ltd. et al. as follows: ${ }^{69}$

... on my construction of s.2(3) [now sec. 3(3)] (the trust provisions of the Ontario Act) it was not its intent to enlarge the unilateral rights of an owner but, rather, to increase the reach of protection available to suppliers and subtrade claimants.

To date the issue has been resolved for the most part in favour of the owner. The interests of those parties on either side of the defective link in the chain have been balanced to a certain extent by providing that there can be no set-off against the statutory holdback. In reality the amount available to claimants is usually small and hardly worth the cost of litigation. And where those down the chain are unable to assert a valid lien claim, because the time for liens has expired or otherwise, or there is no obligation to maintain a holdback, as is being proposed by the Task Force, one could conceivably set off down to zero so that there are no longer any trust funds available to flow down the chain. The rationalization of the Task Force appears to be that the holdback represents such little security for claimants, it will not be a great sacrifice to give it up. However, such hardly seems in keeping with the object of assuring payment to subtrades.

Furthermore, even if the owner or contractor is protected by a performance bond from a surety of the contractor or subcontractor, as the case may be, if the surety is obliged to complete the contract, he is entitled to stand in the shoes of the owner or contractor and claim moneys owing to the defaulting party over and above the holdback in priority to lien and trust claimants. Also, in Ontario if there are no lien claimants or the value of the liens is less than the holdback, then the owner or contractor is able to set off against the holdback as well to the value of the valid liens and will have priority to this extent over trust beneficiaries.

In most provinces the Courts have made it clear that the right of set-off is limited to debts, claims or damages relating to the improvement. One is not permitted to

65. [1969] 1 O.R. 7, 1 D.L.R. (3d) 253 (C.A.).

66. [1929] 4 D.L.R. 32 (Ont. C.A.).

67. (1977) 24 C.B.R. (N.S.) 8, affm'd 23 C.B.R. (N.S.) 244 at p. 12.

68. Supra n.65.

69. (1975) 21 C.B.R. (N.S.) 260 at p. 265.

See also Armco Canada Lid. v. P.C.L. Construction Limited et al. [1986] 4 W.W.R. 624 (leave to appeal to the S.C.C. denied Mar. 23/87) and the discussion below. 
set off on one project amounts relating to other projects or contracts. The one exception to this general rule is Ontario. Section 12 of the Construction Lien Act ${ }^{70}$ states that a trustee can set off "all outstanding debts, claims or damages, whether or not related to the improvement". It is interesting to note that the Draft Construction Lien Act and accompanying Discussion Paper did not recommend that the right of set-off be extended in this manner, nor did the Report of the Attorney General's Advisory Committee. It is possible that this extended right of set-off was thought to be a codification of the law in Ontario in light of the decision of the Ontario Court of Appeal in Royal Trust Co. v. Universal Sheet Metals Ltd. "1 There the trustee in bankruptcy of the contractor set off against the trust funds a debt owed by the contractor to a subcontractor notwithstanding that the debt related to an entirely different contract. The Court applied the provisions of the Ontario Judicature Act which provides for the set-off of mutual debts. Some fourteen years later Fleury L.J.S.C. in Requip (Niagara Falls) Ltd. v. Fort Erie et al. ${ }^{72}$ found a way to distinguish the Universal decision. In Requip the plaintiff was a sub-subcontractor who was claiming a portion of moneys paid into court by the owner in response to notification of lien claims. The subcontractor to whom the plaintiff had supplied materials and the contractor had a long history of dealings and at the relevant time the contractor owed the subcontractor some $\$ 11,000$ relating to the contract. However the subcontractor owed the contractor a much greater sum, albeit all relating to different contracts. The contractor, relying on Universal, alleged that after set-off there was nothing owing to the subcontractor and accordingly any claims arising through that sub must fail. Judge Fleury noted that the provision of the Judicature Act on which Universal relied stated that "Where there are mutual debts between the plaintiff and the defendant . . . one debt may be set against the other." and that in the case at hand, unlike Universal, there were no mutual debts between the plaintiff, the sub-subcontractor, and any of the defendants. He also noted that the Court of Appeal in Universal recognized that the purpose of the trust provisions was to ensure that the benefit of the trust was not diverted from those entitled and that to permit setoff in this situation would indeed divert the benefit of the trust from those further down the chain. Accordingly set-off was not available to the contractor to reduce the amount owed to the subcontractor and the plaintiff was entitled to share in the funds to the extent of the amount owed to the subcontractor. It is submitted that the result in Requip is more in line with the purpose of the trust provisions which is to facilitate the flow of funds down the construction chain and the new Ontario provision goes too far in permitting set-off of unrelated debts. Both Saskatchewan and Alberta in their respective recent Reports considered and rejected the Ontario provision as being contrary to the intended purpose of the legislation.

\section{TO WHOM THE DUTY IS OWED}

Having examined the nature of the trustee's duty under the various builders' lien statutes, the next issue to address is to whom this duty is owed. As we will see, two very distinct approaches have emerged. The first approach was first clearly enunciated in 1963 by the Manitoba Court of Appeal in Royal Bank v. Blick, Wilson et

70. Supra n.38.

71. [1970] 1 O.R. 374.

72. (1984) 17 C.L.R. 134. 
$a l$. The trust provision of the Manitoba Builders and Workmen Act at the time read as follows: ${ }^{73}$
3. All sums received by a builder or contractor or a sub-contractor on account of the contract price shall be and constitute a trust fund in the hands of the builder or contractor, or of the sub-contractor, as the case may be, for the benefit of the proprietor, builder or contractor, sub-contractors, Work- men's Compensation Board, workmen, and persons who have supplied material on account of the contract; and the builder or contractor or the sub-contractor, as the case may be, shall be the trustee of all such sums so received by him, and until all workmen and all persons who have sup- plied material on the contract and all sub-contractors are paid for work done or material supplied on the contract and the Workmen's Compensation Board is paid any assessment with respect thereto, may not appropriate or convert any part thereof to his own use or to any use not authorized by the trust.

Mr. Justice Freedman, as he then was, in considering whether or not the suppliers of a sub-subcontractor were entitled to claim against moneys in the hands of the subcontractor, stated that "the contract" referred to in the provision meant only the specific contract affecting the parties, not the series of contracts comprising the entire project. That is, the contractor would hold the contract price on trust only for those with whom he had contractual privity, the subcontractor would hold funds he received on trust for those with whom he had contractual privity and so on down the chain. Since the claimants had not contracted with the subcontractor they were not beneficiaries of the trust imposed on the funds in the hands of the subcontractor and were not entitled to the funds. The only beneficiary who was entitled to claim against the funds, namely the sub-subcontractor with whom the suppliers had contracted, was unfortunately bankrupt and had neglected to complete his contract. His claim against the trust funds was negated by the cost of completion of his contract which was set off against the amount due to him. It is interesting to note that the party claiming the benefit of the set-off was the surety who had been called on to complete the contract. The result was that the surety was paid in full and unpaid suppliers remained unpaid. The writer would submit that this case was really a case of set-off and with all due respect to the learned Justice, it was not necessary to characterize the structure of the trust as he did in order to achieve the desired result. It appears that the Court assumed that funds impressed with a trust in favour of the suppliers would not be available to the subcontractor to offset the cost of completion. However it would be possible for the suppliers to be beneficiaries of the trust imposed on the funds in the hands of the subcontractor and still not be entitled to any money on the basis that the person through whom the suppliers were claiming was not owed any money as a result of the set-off. This solution was not considered by the Court. In any event the principle enunciated in Royal Bank v. Wilson, commonly known as the privity of trust theory, has grown in popularity and been codified in most of the recently revised builders' lien statutes.

The alternative to the privity of trust theory is that a builders' lien trustee holds the funds in trust not only for those with whom he has contracted directly, but also for everyone down the chain to the last labourer or supplier. At first blush the privity of trust theory is more attractive as the other raises all sorts of questions as to how the trustee is to discharge his obligations to all those beneficiaries or even identify all those beneficiaries. Privity of trust can result in a certain rigidity, however, with consequences which seem contrary to the stated intention of the legislation.

Prior to legislative intervention, there was conflicting case law as to which theory prevailed. In Manitoba, the result in Royal Bank v. Wilson was codified in the new

73. Supra n.41 at D.L.R. p. 40. 
builders' lien legislation enacted in 1981. In Saskatchewan, however, while lower court decisions tended to favour the privity of trust theory, the Saskatchewan Court of Appeal laid the matter to rest in Armco Canada Ltd. v. P.C.L. Construction Limited et al. ${ }^{74}$ The Armco case dealt with the legislation as it existed prior to the new Act which was enacted in 1986. In Armco, the plaintiff was a supplier of a subcontractor which had subsequently become bankrupt and abandoned its contract. The plaintiff argued it was entitled to share in moneys in the hands of the owner on the basis that the moneys were impressed with a trust " for the benefit of the contractor, subcontractor, The Workers' Compensation Board, workmen, and persons who have supplied materials on account of the contract or who have rendered work or services on the contract site". ${ }^{75}$ The Court of Appeal agreed, but with the caveat that the plaintiff was not entitled to any more than that to which the party through which the plaintiff was claiming, namely the bankrupt subcontractor, was entitled. Of course, the Armco decision had little subsequent effect in Saskatchewan as the new builders' lien legislation made it very clear that the beneficiaries were only those with whom the trustee had contractual privity.

There was similar conflicting caselaw in Ontario prior to the new Construction Lien Act which was enacted in 1983. However, the preponderance of cases rejected the privity of trust theory. The most important of these cases was Bre-Aar Excavating Ltd. v. D'Angela Construction (Ontario) Ltd. et al. ${ }^{76}$

In Bre-Aar the plaintiffs were unpaid subcontractors who were alleging breach of trust on the part of the owner. The Mechanics' Lien Act at the time imposed a trust on moneys in the hands of the owner at the time a payment certificate was issued to the extent of the amount certified as payable under the contract to the contractor. The architect who had been asked to issue a progress certificate was aware of the precarious financial position of the contractor and suspected that any contract moneys received by the contractor would be diverted from those claiming through the contractor in breach of the contractor's trust obligations. The architect wrote a letter to the owner informing the owner of his concerns and recommending that the owner not pay the contract moneys directly to the contractor, but instead pay the moneys into a trust fund until the matter could be resolved. The architect also enclosed the progress certificate with the letter. The owner ignored the advice of the architect and paid the contractor. The contractor diverted the funds, became insolvent and the subcontractors remained unpaid. The owner defended its actions by relying on the provision which stated that the funds were trust funds in the hands of the owner until paid to the contractor (emphasis mine). In essence the owner was arguing that its only obligation as a trustee was to pay the trust moneys and upon doing so it had discharged its obligation. Killeen Co. Ct. J. refused to accept this argument. He held that the moneys in the hands of the owner constituted a trust fund for the benefit of the contractor and the other beneficiaries enumerated in the relevant section of the Act. In view of the notice received by the owner of the financial delinquency of the contractor, the owner had not acted reasonably in making the payments to the contractor and was therefore not entitled to rely on the statutory discharge. He noted that the owner may have been acting in good faith, but

74. Supra n.69.

75. Mechanics' Lien Act, R.S.S. 1978, c.M-7, as am., s.3.

76. Supra n.69. 
had not acted reasonably. Consequently the owner was liable to the subcontractors for their loss. Clearly this duty owed to the subcontractors arose out of the trust relationship between the owner and the subcontractors. Although the duty of the builders' lien trustee in the ordinary course of things is simply to pay the party with whom he has contractual privity, once the owner has notice of impending harm to other beneficiaries down the chain, the owner's obligation expands to require him to act in a reasonable fashion to protect the interests of the other beneficiaries. Clearly, if the requirement of privity of trust were imposed on this situation, the owner would have no duty to anyone except those with whom he had privity of contract and could have paid the money to the contractor without any concern for what would happen to the money in the contractor's hands. The effect of the Bre-Aar case was cut short by the enactment of the new Construction Lien Act in Ontario in 1983 which made the necessity of privity of trust clear.

In both New Brunswick and British Columbia the courts have rejected the privity of trust theory and the respective legislatures have yet to intervene. In New Brunswick the latest pronouncement was from the New Brunswick Court of Appeal in Saint John Tile and Terrazzo Co. Ltd. v. Harding Carpets. ${ }^{n}$ In British Columbia the lower courts tended to favour the privity of trust theory until the Court of Appeal set the matter to rest in 1978 in Cronkhite Supply Ltd. v. W.C.B. et al. ${ }^{78}$ The relevant provision of the B.C. Mechanics' Lien Act provided then, as it does now, as follows:

3.(1) All sums received by a contractor or sub-contractor on account of the contract price are and constitute a trust fund in the hands of the contractor or of the sub-contractor, as the case may be, for the benefit of the owner, contractor, sub-contractor, Workmen's Compensation Board, workmen, and material-men; and the contractor or the sub-contractor, as the case may be, is the trustee of all such sums so received by him, and, until all workmen and all material-men and all subcontractors are paid for work done or material supplied on the contract and the Workmen's Compensation Board is paid any assessment with respect thereto, shall not appropriate or convert any part thereof to his own use, or to any use not authorized by the trust.

The B.C. Supreme Court had previously held in Crane Canada Limited v. McBeath Plumbing \& Heating Ltd. et al. .9 that the "contract price" referred to in this section meant each individual contract and thus there was a series of trusts, the beneficiaries of which were those in contractual privity with each trustee. The concern was expressed that otherwise it could be argued that the moneys received by one subcontractor were trust funds for those claiming under other subcontractors and one could never be sure of identifying all the beneficiaries and sorting out the priorities. Taggart J.A., speaking on behalf of the Court of Appeal in Cronkhite, rejected this interpretation, stating " . . . the terms "contract" and "contract price" are used in s. 3 to describe in a compendious way the various contracts and contract prices involved in the overall project. To hold otherwise would severely limit the benefits to be derived by the classes of beneficiaries referred to in the section." 80 Mr. Justice Taggart dealt with the concern raised in Crane by stating that, while the money received by a head contractor is impressed with a trust for everyone down the chain and claimants may follow trust moneys at any point in the chain, they may do so only in a direct line upward. "They cannot claim against moneys

77. Supra n.62.

78. (1978) 91 D.L.R. (3d) 423, 8 B.C.L.R. 54, 7 R.P.R. 121, affm'd on other grounds [1979] 2 S.C.R. 27.

79. (1965) 54 W.W.R. 119.

80. Supra n.78 B.C.L.R. at p. 65. 
received by a collateral subcontractor who has received moneys from the head contractor for to do so would result in the workmen, material-men and subsubcontractors of that collateral subcontractor being denied payment of moneys which are properly theirs. To put it perhaps in a colloquial way, the claims under s. 3 (trust claims) may be made vertically but not laterally." 81

A question unanswered by the Cronkhite case was subsequently dealt with by the B.C. Court of Appeal in Mackenzie Redi-Mix Co. Ltd. v. Miller Contracting Ltd. et al..$^{82}$ The question not decided by Cronkhite was, given that a person with trust funds is trustee for everyone down the chain, has he fully discharged his obligations when he has fully paid the parties with whom he contracted? The Court of Appeal answered in the affirmative with the following explanation: ${ }^{83}$

If a contractor who has paid a subcontractor in full may also be liable for that subcontractor's debts to materialmen, he will be unwilling to pay the subcontractor without assurances that those below in the construction chain have already been paid. The subcontractor will have to pay those materialmen before receiving contract moneys from the contractor, but from what funds is the subcontractor to make such a payment? The logical flow of money is from the contractor to the subcontractor and then to the materialmen. This payment flow will be hindered if each trustee must ensure that all those below have been paid before he pays those with whom he contracts.

The Court also pointed out that if its interpretation were otherwise, none of the contractors or subcontractors could appropriate any of the contract moneys to expenses or overhead nor take any profit until the whole project was complete and they were sure that everyone was fully paid. Mr. Justice Seaton thought it "particularly unlikely that the legislature would have considered as breach of trust the application of some of the moneys to the expenses of the contractor or subcontractor when everyone with whom he had a contract had been paid in full." 84 The result in Mackenzie was, therefore, that the appellant, who was an unpaid supplier of a subcontractor, was not entitled to be paid from any contract moneys in the hands of the contractor because the contractor had already paid to the subcontractor, through whom the appellant claimed, all money that was due and owing to it. The subcontractor in this case had only partially completed its contract before becoming insolvent and abandoning it. However, the Court made it clear that the result would have been the same if the subcontractor had finished the job and been paid the entire contract price.

The fact that British Columbia is one of the few provinces in which the privity of trust theory does not prevail is somewhat surprising in view of the strong recommendations for privity of trust contained in the British Columbia Law Reform Commission's report issued in $1972 .{ }^{85}$ The main concern expressed by the Commission in its report appears to be that addressed by the B.C. Court of Appeal in Mackenzie, namely how a trustee discharges his obligation. The Commission obviously interpreted the provision as meaning that everyone must be paid before the contractor or subcontractor can appropriate any money, something the Commission understandably viewed as "an alarming proposition". The solution which was obvious to the Commission was the imposition of the requirement of privity of trust. Unfortunately it did not consider the solution found by the Court of Appeal

81. Id. at p. 66.

82. (1988) 46 D.L.R. (4th) 570,20 B.C.L.R. (2d) 283.

83. Id. B.C.L.R. at p. 287.

84. Id.

85. Supra n.21. 
in Mackenzie. Despite the strong recommendation of the Law Reform Commission, the trust provision remained unchanged when the British Columbia statute was amended in 1979 and privity of trust is not part of the law of British Columbia to this day.

The legislative process in the three provinces which have recently codified the privity of trust theory has also been interesting. The most recent Builders' Lien Act in Saskatchewan clearly adheres to privity of trust. The trust imposed on funds in the owner's hands is for the benefit of the contractor; the trust imposed on funds received by the contractor or owing to the contractor is for the benefit of subcontractors, suppliers and labourers, all of whom have contracted with the contractor for the purpose of the project. The Report of the Special Advisory Committee to the Minister of Justice on Builders' Liens which was released in $1984^{86}$ is interesting in that the authors assumed that the then current provisions required privity of trust despite the words of the statute which specified that the contract price was held on trust by the contractor and subcontractor for the benefit of "the owner, builder, contractor, subcontractor, the Workers' Compensation Board, workmen, materialmen and persons who have supplied services". Of course the Committee did not have the benefit of the decision of the Saskatchewan Court of Appeal in Armco at that time. However, the case authority provided by the Committee in support of its claim that privity of trust was the law in Saskatchewan was particularly weak ${ }^{87}$ Unfortunately the issue appears to have been decided in favour of privity of trust with little consideration of any alternative.

In Manitoba the case law had been clearly decided in favour of privity of trust in Royal Bank v. Wilson. ${ }^{88}$ The Manitoba Law Reform Commission's 1979 Report ${ }^{89}$ recommended both preservation of this doctrine and amendment of the statutory provisions to clarify same. The adoption of these recommendations is for the most part reflected in the new Builders' Liens Act ${ }^{90}$ which was enacted in 1981, however, the legislation is far from clear. For example, the trust imposed on moneys in the hands of the owner is for the benefit of not only the contractor, but also all subcontractors and others who have supplied materials or provided services on the contract or any subcontract under the contract, the Workers' Compensation Board and workers employed under the contract or any subcontract under the contract. Clearly privity of contract is not necessary to be a beneficiary of the owner's trust. The Act then switches to privity of trust when setting out the respective trust obligations of the contractor and subcontractor. However, one of their obligations is to provide for the payment of "other affected beneficiaries of the trust" which casts some doubt on the strictness of the privity of trust doctrine as set out in the legislation. The relevant provisions of the Manitoba Act are as follows: ${ }^{91}$

86. Supra n.28.

87. The authority provided was Westem Supplies Limited v. Cana Construction Company [1976] 1 W.W.R. 289 (Sask. D.C.) which dealt with The Public Works Creditors ' Payment Act, not the Mechanics' Lien Act (as it was then).

88. Supra n.41.

89. Supra n.26.

90. Supra n.60.

91. Id. 


\section{RECEIPTS OF CONTRACTOR CONSTITUTE TRUST FUND}

4(1) All sums, including any interest on the holdback, received by a contractor on account of a contract price constitute a trust fund for the benefit of

(a) sub-contractors who have sub-contracted with the contractor and other persons who have supplied materials or provided services to the contractor for the purpose of performing the contract;

(b) the Workers' Compensation Board;

(c) workers who have been employed by the contractor for the purpose of performing the contract; and

(d) the owner for any set-off or counterclaim relating to the performance of the contract.

DUTIES OF CONTRACTOR RESPECTING TRUST FUND

4(3) A contractor receiving a sum mentioned in subsection (1) is the trustee of the trust fund and he shall not appropriate or convert any part of the trust fund to or for his own use or to or for any use not authorized by the trust until

(a) all sub-contractors who have entered into a sub-contract with him and all persons who have supplied materials or provided services to him for the purpose of performing the contract have been paid all amounts then owing to them out of the sum received;

(b) the Workers' Compensation Board has been paid all assessments which the contractor could reasonably anticipate as arising out of work done by workers employed by him in performing the contract to the extent for which the sum was received;

(c) all workers who have been employed by him for the purpose of performing the contract have been paid all amounts then owing to them out of the sum received for work done in performing the contract; and

(d) provision has been made for the payment of other affected beneficiaries of the trust to whom amounts are then owing out of the sum received. (emphasis mine)

\section{RECEIPTS AND MONEYS OF OWNER CONSTITUTE TRUST FUND}

5(1) Where, under a contract, sums become payable to the contractor by the owner on the basis of a certificate of a payment certifier, any amount up to the aggregate of the sums so certified, that is in the hands of the owner or received by him at any time thereafter for payment under the contract constitutes, until paid to the contractor, a trust fund for the benefit of

(a) the contractor and all sub-contractors and other persons who have supplied materials or provided services for the purposes of performing the contract or any sub-contract under the contract;

(b) the Workers' Compensation Board; and

(c) workers who have been employed for the purpose of performing the contract or any subcontract under the contract.

As we can see, section 4(1) clearly names four beneficiaries of the contractor's trust, namely the subcontractors and suppliers who have contracted with the contractor, the Workers' Compensation Board, workers employed by the contractor and the owner, to the extent that he has a right of set-off or counterclaim. Section 4(3) which sets out the duties of the contractor names the first three beneficiaries, but then refers to "all other affected beneficiaries". According to section 4(1) the only remaining beneficiary who has not been mentioned is the owner, but the reference in section 4(3) to "beneficiaries" is plural raising questions in this writer's mind and others ${ }^{92}$ as to what exactly was intended by the legislators. It does, of course, open the door to the argument that the contractor owes a duty to everyone down the chain and it will be interesting to see how this apparent ambiguity is resolved by the courts.

The privity of trust doctrine is also evident in the new Ontario Construction Lien Act enacted in 1983. However, the final result was not necessarily reflected in the draft legislation and reports which preceded it. The draft legislation and accompanying commentary released by the Ontario Ministry of the Attorney General in

92. See T.G. Frohlinger, “A Practical Guide to the Builders' Liens Act (Manitoba)” (1983) 12 Man. L.J. 357. 
1980 reflected the then current case law on the obligations of the builders' lien trustee in Ontario, namely Dominion Electric Protection Co. v. Leopold Beaudoin Const. Co. ${ }^{93}$ and Bre-Aar Excavating Ltd. v. D'Angela Construction (Ontario) Ltd. et al. ${ }^{94}$ The trust provisions of the discussion draft indicated that a trustee held the contract price on trust for everyone down the chain and a unique provision was included which specified that where a trustee had received notice that payment to a creditor/beneficiary would likely result in that creditor/beneficiary committing a breach of his trust obligations, the trustee was obliged to withhold from the creditor/beneficiary the amount claimed in the notice and either pay the other beneficiary the amount claimed on the agreement of the involved parties, or to pay the amount into court by way of an interpleader application. ${ }^{95}$ This latter provision was clearly a codification of Bre-Aar. As mentioned above, application of the principle in Bre-Aar is possible only where privity of trust is not required.

The provision of the discussion draft containing the Bre-Aar principle did not find favour in the Report of the Attorney General's Advisory Committee on the Draft Construction Lien Act released in 1982.96 The Committee's concern was that the proposed provision would compel a trustee wishing to pay trust money to decide whether or not he had any notice of an impending problem and cautious payers would seriously disrupt the flow of funds and clog the courts with interpleader applications. The Committee also thought that the existing lien rights gave sufficient protection to a claimant who was worried about a breach of trust. The Committee did not however indicate how the lien provisions would operate to prevent an impending breach of trust suspected by a subcontractor or supplier who, because of the nature of his contract, was not entitled to a lien because he was not as of yet entitled to be paid. Beyond its concerns with respect to the Bre-Aar principle, the Committee did not address the issue of privity of trust, but seems to have assumed that upon rejection of the Bre-Aar principle it also must reject the idea that a trustee could hold on trust for more than those with whom the trustee had contractual privity. It is interesting that the trust provisions in the revised draft legislation produced by the Committee did not contain a clear statement of the privity of trust doctrine even though it would appear that the Committee thought that it did. It is unfortunate that the Committee did not consider alternatives to the provisions contained in the discussion draft which did not involve eliminating the principles altogether. Even the Bre-Aar principle is potentially salvageable if the onus for determining whether or not there had been notice of a breach of trust is removed from the payer. For example, an owner could be free to pay contract moneys to the contractor without any obligation to others down the chain unless he had received written notice in a prescribed form of an actual or impending breach of trust at which point he would be obliged to withhold from the amount then owing to the contractor, if any, a sum equal to the amount claimed in the notice.

Since it is the writer's opinion that Saskatchewan and Ontario, and to a lesser degree Manitoba, moved to strict privity of trust without thoroughly considering its advantages and disadvantages (at least not in their respective reports), it is

93. (1963) 5 C.B.R. (N.S.) 72 (Ont. S.C.).

94. Supra n.69.

95. S.10 of the Draft Construction Lien Act.

96. Supra n.27. 
appropriate to go through the exercise at this point. The two main advantages of imposing privity of trust on a builders' lien trust scheme are: 1) simplicity for the trustee in that he knows exactly who the beneficiaries of the trust are (those with whom he has contractual privity), and 2) it maintains an orderly flow of funds down the chain. A further argument in favour of privity of trust is that there is no need for a trustee to owe a duty to anyone further down the chain who might be affected by a breach of trust committed by someone other than the trustee because that person down the chain can file a lien if he wants to stop the flow of funds. The main disadvantage of the privity of trust doctrine is its rigidity in that a sub-subcontractor or supplier way down the chain has limited ability to bring an action to enforce a trust further up the chain or attach moneys further up the chain. Instead the subsubcontractor or supplier must wait for funds to "trickle down". If a link in the chain is bankrupt or insolvent before receiving trust funds, those further down must wait for a trustee in bankruptcy or receiver to be appointed and then run the risk of having to fight with the trustee in bankruptcy or receiver over what funds are subject to the trust. Also, in the event a link in the chain fails to take action to enforce the trust of which he is a beneficiary, others down the chain may face difficulties in bringing an action to enforce a trust of which they are not direct beneficiaries. Either they may not be permitted to enforce a trust of which they are not beneficiaries or the court may find itself standing on its head and straining the facts in order to find privity of contract where none really exists. A perfect illustration of this situation is found in Saint John Tile and Terrazzo Co. Ltd. v. Harding Carpets ${ }^{97}$ (hereinafter referred to as the "Harding" case). Harding Carpets ("Harding") was the supplier of carpet on a major hotel project. The contractor on the project was Rocca Construction Ltd. ("Rocca") which had subcontracted with Saint John Tile and Terrazzo Ltd. ("Tile") for both the supply and installation of all the carpet. Tile, in turn, subcontracted with its wholly owned subsidiary, B \& N Flooring Supplies Ltd. ("B \& N') which ordered the carpet from an Ontario broker, Dennis Wilder Enterprises Limited ("Wilder") which, in turn, ordered the carpet from Harding. The carpet was delivered to the site by Harding where it was installed by Tile. Harding's invoice to Wilder was approximately $\$ 58,000$ and Wilder's invoice to B \& N was approximately $\$ 80,000$. Tile and Rocca were involved in another project, a senior citizen's complex, which involved carpet supplied by Wilder and in respect of which Rocca claimed a deficiency of $\$ 50,000$. Rocca paid Tile some $\$ 160,000$, representing the full amount owing to Tile on the hotel project and the senior citizen's project on the condition that Tile immediately remit back to Rocca the sum of $\$ 50,000$ representing the deficiency claimed on the senior citizen's project. Tile complied with this condition. Tile then paid $\$ 40,000$ to B \& $N$ which immediately paid the $\$ 40,000$ to Wilder. $B \& N$ then prepared a cheque for Wilder for the amount which remained owing to Wilder, but this cheque was never signed because B \& N did not receive any more funds from Tile. So Wilder received half of what it was owed, but Harding received no money whatsoever from Wilder. Harding sued Wilder in Ontario and obtained a judgment which remained unsatisfied. Harding then sued Tile on the basis that the funds Tile had received from Rocca were subject to a trust of which Harding was a beneficiary and Tile had misappropriated part of these funds by applying them to an unrelated project. The amount which Harding claimed was the amount then still owing to Wilder,

97. Supra n.62. 
namely some $\$ 40,000$. Tile argued that Harding was not a beneficiary to whom Tile owed any duty because there was no privity of contract between Harding and Tile. The trial judge assumed that privity of contract was necessary in order for Harding to succeed, but nonetheless found in favour of Harding by deciding that Tile and $B$ \& $N$ were for all essential purposes one and the same and that Wilder was out of the picture because once Wilder had placed the order with Harding, Harding had dealt directly with a fellow, Craft, who was the manager of both Tile and $B$ \& N. Consequently the trial judge determined that Harding and Tile did have privity of contract. With all due respect to the trial judge, his ruling stretched the facts somewhat. It does, however, indicate that the trial judge felt he had no alternative if Harding was to succeed.

The New Brunswick Court of Appeal upheld the decision in favour of Harding, but for quite different reasons than those expressed by the trial judge. The Court of Appeal rejected the privity of trust theory and determined that Harding was a beneficiary of the trust imposed on the funds in the hands of Tile even though there was no privity of contract between the two. The nature of the legislation in New Brunswick permitted this interpretation by the Court of Appeal that privity of trust was not required. In a province such as Saskatchewan or Ontario, however, presumably a claimant in the position of Harding would be out of luck unless the court could somehow find privity as did the trial judge in Harding or the court was willing to entertain an action to enforce a trust brought by a person who is not a beneficiary of the trust, but who does have an interest in seeing the trust properly administered. It may well be that such an action is possible where the breach of trust has occurred only one step up the chain and the trustee of the claimant has refused or neglected to take action to rectify the breach. For example, where as between the contractor and a subcontractor the contractor sets off against trust funds an amount which relates to another project and the subcontractor does not challenge this set-off, a worker employed by the subcontractor probably could successfully challenge the set-off on the basis that he is a beneficiary of the trust imposed on funds in the subcontractor's hands and is consequently subrogated to the rights of his trustee..$^{98}$ But what about someone even farther down the chain, such as the supplier of a sub-subcontractor. If the funds which have been subjected to the disputed set-off have not yet flowed down then his trustee has not even become a trustee yet. On what basis could this supplier leapfrog several steps above him in the chain to challenge this set-off which will ultimately affect him? Could it be that the courts would view this supplier as having an equitable interest in the moneys far up the chain which is sufficient to support his action? Could it not also be argued that even if this equitable right did exist, it had been displaced by the very terms of the statute which specify exactly for whose benefit the funds are held?

Even if a person far down the chain does have an interest in moneys at the beginning of the chain which is sufficient to support an action to challenge a breach of trust occurring near the beginning of the chain, what about the situation where a breach of trust has not yet occurred and the action is purely preventative? On what basis could the courts find that a non-beneficiary was entitled to attach trust moneys in that situation? An example of this situation is found in Armco Canada Ltd. v. P.C.L. Construction Limited et al. ${ }^{99}$ As mentioned above, the plaintiff in Armco

98. See Waters, Law of Trusts in Canada supra n.7 at p. 985.

99. Supra n.69. 
was the supplier of a subcontractor who had become bankrupt and abandoned its contract leaving the plaintiff unpaid. The project was substantially complete and the owner was about to release the holdback on the entire project which amounted to over \$1 million. The plaintiff wished to attach the funds in the hands of the owner on the grounds that it was a beneficiary of the trust imposed on those funds and was entitled to be paid from them. P.C.L., the contractor on the project, argued first that the plaintiff was not a beneficiary of the trust imposed on the funds and second, that the plaintiff was not entitled to any moneys because the subcontractor through whom the plaintiff was claiming was not entitled to any moneys after the cost of completing the subcontractor's contract was subtracted from what had been owing to it by P.C.L. As we know, the Saskatchewan Court of Appeal held that the plaintiff was a beneficiary of the trust imposed on the funds in the hands of the owner and that the plaintiff was entitled to be paid from those funds to the extent that money was owed to the subcontractor. The Court also determined that the sum owed to the subcontractor was not subject to set-off, but that was a separate issue. Imagine if you will that the Court had held instead that the plaintiff was not able to succeed because it did not have privity of trust with the owner. The funds would have been paid to P.C.L., which in turn would not have paid anything to the trustee in bankruptcy of the subcontractor because P.C.L. believed it was entitled to set off the costs of completion it had incurred against the value of the work completed by the subcontractor prior to abandoning its contract. Then either the trustee in bankruptcy or the plaintiff supplier would have to sue P.C.L. challenging this setoff. Presumably the suit would be successful, but what guarantee would the plaintiff have that his judgment would be satisfied? In this particular situation the plaintiff would be fortunate that the contractor was P.C.L., a very large, solvent company, but many contractors are not of that kind. Under the privity of trust doctrine the person down the chain would have to wait for funds to trickle down to his level and then hope that his claims could be satisfied.

That being the operation and parameters of the privity of trust doctrine, what are the advantages and disadvantages of not requiring privity of trust? The advantage of imposing a trust on the contract moneys which is for the benefit of everyone in the chain is simple. It means greater protection for those further down the chain. It means that the suppliers, sub-subcontractors, and subcontractors can get at trust money directly when there is a problem with a link in the chain. They can possibly prevent a breach of trust or prevent a further breach of trust and they do not have to rely on others further up the chain to do this on their behalf. The main disadvantage of not requiring privity of trust is also simple. It means greater uncertainty for a trustee and the interposition of obligations towards persons with whom the trustee has no other nexus. If a trustee is responsible for everyone down the chain then how can he pay the person to whom he is obliged by contract without first ensuring that the money will indeed flow down as is intended? Such were the concerns raised by the Bre-Aar ${ }^{100}$ case in Ontario. Also, if a beneficiary can attach funds in the hands of the owner, could not the owner potentially be forced to pay more than the contract price if he wants his project complete. An example may illustrate. A project is complete except for the landscaping which represents $10 \%$ of the value of the entire contract. The owner pays $90 \%$ of the contract price to the contractor. There

100. Supra n.69. 
is a defalcation somewhere in the chain and the supplier to the plumbing subcontractor remains unpaid. If privity of trust is not required then presumably the unpaid supplier can attach the moneys remaining in the owner's hands even though the owner has already paid for the plumbing because the trust attaches to aggregate of the funds in the hands of the owner. There is not a plumbers' trust and an electricians' trust, etc. The owner would have to pay the money to the unpaid supplier, and once the landscaper finds out that there is no more money, he is unlikely to do any landscaping and the owner ends up with an incomplete job for the contract price. His only remedy may be to sue the contractor for breach of contract. One argument that may be raised on behalf of the owner is that the funds remaining in the hands of the owner are not subject to a trust because they are not yet owing to the contractor because the landscaping work has not yet been done. Yet if we look at most of the trust provisions dealing with the trust imposed on the owner, we see that the trust arises not only when moneys are owing to the contractor, but when funds are received by the owner to be used in financing the project and, if the recommendations of the Task Force are accepted, when the owner has identified to the contractor funds or a source of funds to be used to finance the project. Another argument that could be raised is that the owner's liability is limited to the amount of the statutory holdback and beyond the holdback the owner is not liable for more than the contract price. This argument may be possible where a holdback is required by statute, but what if there is no holdback required as is being proposed by the Task Force?

The solution to the first of these problems is quite straightforward. It is that proposed by the British Columbia Court of Appeal in Mackenzie Redi-Mix Co. Ltd. v. Miller Contracting Ltd. et al. ${ }^{101}$ namely that a builders' lien trustee holds the contract funds on trust for everyone down the chain, however his only duty is to pay those to whom he has a contractual obligation the money owed. Once the trustee has paid, he has discharged all obligations. A further question not dealt with by the Court of Appeal in Mackenzie is whether or not the trustee should be so discharged if he pays in the face of notice of an impending breach of trust (the BreAar situation). Clearly a trustee with such notice should not be able to ignore the interests of beneficiaries down the line. However, rather than putting the onus on the trustee to determine whether or not he has been notified of circumstances to which he is obliged to respond, why not create a procedure by which a beneficiary can give formal written notice to the trustee to stop the trustee from paying any further moneys? If the trustee has not received such a notice then he may pay the money and discharge all his obligations. If he has received such notice then he is obliged to withhold payment for a specified length of time. If the parties are able to resolve the matter the trustee may then pay the moneys. If the matter is not resolved, the trustee must pay the money into court and the conflicting claims will then be sorted out by the court. This is of course the general idea of the Stop Notice proposed by the Task Force and, as we will see later on, there may be some merit in this proposal.

The solution to the second problem is more elusive. If a beneficiary is permitted to attach moneys in the hands of the owner before the contract is complete, then it is possible that the owner may have to expend more than the original contract price in order to have the job finished. This problem was alluded to in Armco Canada 
Ltd. v. P.C.L. Construction Limited et al. ${ }^{102}$ which you will recall was a decision of the Saskatchewan Court of Appeal that privity of trust and set-off were not part of the law of Saskatchewan and consequently an unpaid supplier was permitted to share in the funds remaining in the hands of the owner. In that particular situation, however, the owner suffered no loss as the contract was complete and was a fixed price contract. Therefore the loss would be borne not by the owner, but by the contractor, P.C.L. The rationale offered by the Court was that the whole object of the Act was to protect those at the bottom of the construction pyramid. Furthermore, the contractor was the one who chose the subcontractors and was well positioned to protect itself from the consequences of defalcation on the part of a subcontractor by obtaining a performance bond. Generally, the contractor was able to exercise considerable control over the entire project, including financial control. Certainly to a much greater extent than sub-trades or suppliers. While this rationale may be attractive in relation to contractors, it is more difficult to apply to an owner. Certainly an owner does not exercise control over a project as does a contractor. The owner is, however, in a position to obtain a performance bond with respect to the contractor. Any loss would then be borne by the surety.

The problem is similar to that discussed above in relation to set-off. A solution is not readily available mainly because it is a problem of risk allocation. When there is a shortage of funds who will bear the loss? Will it be the contractor or possibly the owner or should it be the sub-subcontractors and suppliers? When the choice is between the owner and the sub-subcontractors we run into conflicting principles. The first is that the Act is to protect those far down the chain; the other is that the owner should not be liable for more than the contract price. As we have seen, in most provinces the latter principle prevails, with the only requirement being that the owner comply with the statutory holdback.

\section{E. REMEDIES OF THE BENEFICIARY}

It has been clearly established that failure to comply with the trust provisions results in civil liability. ${ }^{103}$ The remedy is entirely separate from the lien ${ }^{104}$ and is not dependant upon the plaintiff having the right to enforce a lien. It is also a distinct cause of action separate from the right to sue for breach of contract. For example, a supplier who obtains a judgment for breach of contract against the subcontractor may also sue the contractor for breach of trust. ${ }^{105}$

In an action for breach of trust the beneficiary is entitled, as in contract and tort, to be compensated for the loss sustained. An advantage of the action for breach of trust is, however, that the remedy may be either personal, against the trustee, or proprietary, to recover the trust property itself. ${ }^{106}$ This can be of great advantage

102. Supra n.69.

103. See Macklem and Bristow, Construction and Mechanics' Liens in Canada supra n.8, MinneapolisHoneywell Regulator Co. Lid. v. Empire Brass Manufacturing Co. Lsd. supra n.6, Emco Supply; A Division of Emco Ldd. v. Guegin et al. supra n.48, Henry Electric Ld. et al. v. Farwell supra n.48, Horsman Bros. Holdings Lid. et al. v. Dahl et al. supra n.48, Edward Wilson et al. v. Parkin Enterprises Ld. et al. (1988) Man. R. (2d) 314, 32 C.L.R. 63 (Q.B.).

104. Minneapolis-Honeywell Regulator Co. Lid. v. Empire Brass Manufacturing Co. Ldd. supra n.6.

105. Dominion Electric Protection Co. v. Beaudoin Const. Co. supra n.93 and Saint John Tile and Terrazzo Co. Ltd. v. Harding Carpets supra n.62.

106. See Waters, Law of Trusts in Canada supra n.7 at p. 1033. 
where the trustee is insolvent, assuming of course that the trust property may be traced. If the trust property has gone to a bona fide purchaser for value who had no notice of the beneficiary's interest in the property, then it is lost to the beneficiary. ${ }^{107} \mathrm{~A}$ further advantage enjoyed by the trust beneficiary is that the property of the trust in the hands of a bankrupt trustee does not form part of the assets of the bankrupt and is not subject to distribution to the creditors of the bankrupt pursuant to the provisions of the Bankruptcy Act. ${ }^{108}$

Many of the cases involving a breach of the builders' liens trust provisions are suits against not only the trustee, but also the bank at which the trust funds were held on deposit. The usual scenario is that the contractor/trustee deposited trust funds to his general operating account and the bank "scooped" the funds to cover outstanding loans to the contractor. At this point the beneficiary has an action against the contractor/trustee for breach of trust. However, if the contractor is insolvent, which is often the case, the beneficiary will have difficulty recovering anything from him. The bank will be considered a bona fide purchaser for value and the beneficiary will be unable to follow the funds into the hands of the bank unless he can establish that the bank had notice, actual or constructive, of the beneficiary's interest in the funds. If the bank did have such notice, then the bank will be held to have participated in the breach and be jointly and severally liable for the breach along with the contractor/trustee.

One of the first cases dealing with knowledge on the part of the bank of a breach of trust was Fonthill Lbr. Ltd. v. Bank of Montreal. ${ }^{109}$ In Fonthill the Ontario Court of Appeal determined that the manager of the bank had been advised of the nature of the deposits made to the account and was presumed to know the provisions of the trust sections of the builders' lien legislation. From the facts it was evident that the manager should have known the contractor was having difficulty paying its debts and that it was likely that there were unpaid subcontractors and suppliers. Also, the bank could not argue that it received the funds in the ordinary course of business because the deposit in question was made with the express request that it be applied to the indebtedness of the contractor. Fonthill was followed by a series of cases, beginning with John M.M. Troup Ltd. v. Royal Bank, ${ }^{110}$ a decision of the Supreme Court of Canada, in which the bank was found to have received the funds in the ordinary course of business and accordingly was not liable to the beneficiary. An exception was the Supreme Court of Canada's decision in Re John Ritchie Limited; The Clarkson Co. Ltd. v. Canadian Bank of Commerce. "'1 In Ritchie the contractor had borrowed money from the bank which it had used to partially discharge its obligations to subcontractors, employees and suppliers. The contractor received the final payment from the owner, paid same into its general account and wrote cheques on the account to subcontractors. The bank dishonored the cheques and applied the funds to the contractor's overdraft. The Court found that the bank was aware that the money was received by the contractor on account of the contract and was subject to a trust and also that there were unpaid

107. Id.

108. R.S.C. 1970 , c.B-3, s.47(a).

109. [1959] O.R. 451, 38 C.B.R. 68, 19 D.L.R. (2d) 618 (C.A.). Also see case comment by M. Burgard at (1961) 2:262 Osgoode Hall L. J. 262.

110. Supra n.36.

111. Supra n.48. 
beneficiaries, since the bank had dishonored cheques to those beneficiaries. Consequently the bank was a trustee de son tort and was liable to the beneficiaries. It is interesting to note that one of the Bank's arguments was that it was simply applying the funds to the repayment of a loan, the proceeds of which were used to pay trust beneficiaries, as the contractor was entitled to do. The Court held, however, that this discretion could be exercised only by the trustee and could not be delegated to the bank. It was clear that the contractor had not elected to apply the moneys to the loan as the contractor had written cheques to the beneficiaries.

The trend in more recent cases seems to be to find liability on the part of the banks. Indeed the courts seem willing to impose a greater obligation on the banks to make enquiries whether or not an appropriation of the funds would be diverting the funds from trust beneficiaries. The principles derived from a number of cases were set out by the B.C. Supreme Court in Johnson Controls Ldd. v. Avitan Mechanical Installations Ltd. ${ }^{112}$ and quoted by McKay J. in Westex Manufacturing Ltd. v. Wilson et al. as follows: 113

First, did the bank know that the moneys being deposited by its customer were trust moneys? In the case of moneys impressed with the statutory trust under s.2 of the (B.C.) Act such knowledge can be imputed to the bank in proper circumstances. See Fonthill Lumber Ld. v. Bank of Montreal, 19 D.L.R. (2d) at p. 629 and the John M.M. Troup case, supra, at p. 570 [D.L.R.].

If it is shown that the bank did not have knowledge that the funds deposited were impressed with a trust and that there were no facts and circumstances of which it had knowledge which should have put it on inquiry then the bank would not be liable for any appropriation of the funds deposited. If knowledge of the character of the funds as trust funds is brought home to the bank then the second inquiry is whether the bank had actual knowledge of the fact that there were trust beneficiaries whose accounts were unpaid. See the John M.M. Troup case, supra, at pp. 270-71.

If it is demonstrated that the bank did not have such actual knowledge, then the third inquiry is whether the bank had knowledge of facts and circumstances sufficient to put it on inquiry. See the Perlmutter Shore case, supra, at pp. 583 and 584 [O.R.].

Finally it is necessary to determine whether the bank has received and applied the funds in the ordinary course of business without knowledge of any unusual circumstances. If so, it does not participate in a breach of trust: see Port Coquitlam Bldg. Supplies Ld. v. Royal Bank of Can., supra, per Andrews.

What this means is that if the bank is aware that its customer operates as a contractor or subcontractor and the funds deposited to the account are proceeds of building contracts, then the bank is taken to be aware of the provisions of the relevant builders' lien statute which operate to impress the funds with a trust to the extent that there are unpaid beneficiaries. If the bank is unaware of the nature of the customer's business and there are no other circumstances to put the bank on inquiry, then that is the end of the matter. If, however, the bank is aware or should be aware that the funds are subject to a statutory trust, then the next step is to determine whether or not the bank is aware, or should be aware, that there are unpaid beneficiaries. The bank will be taken to be aware of unpaid beneficiaries in circumstances such as where it has dishonoured cheques to beneficiaries, ${ }^{114}$ or is otherwise aware that the customer is experiencing severe financial difficulties. ${ }^{115}$

112. (1985) 12 C.L.R. 159 at p. 163.

113. (1986) 21 C.L.R. 133, followed in Heating Engineering Installations Ld. v. Raymond Contracting Lid. et al. supra n.48.

114. As in Fonthill Lumber Lid. v. Bank of Montreal supra n. 109 and Re John Ritchie; The Clarkson Co. Lid. v. C.I.B.C. et al. supra n.48.

115. As in Perlmutter Shore Ld. v. Bank of Montreal supra n.48, Overhead Door Company of Regina (1973) Led. v. SEDCO et al. supra n.48 and Heating Engineering Installations (1981) Ld. et al. v. Raymond Contracting $L d$. et al. supra n.48. 
This duty of inquiry which has been imposed on the banks has been held to not conflict with what is now section 206(1) of the Bank Act ${ }^{116}$ which states that "The bank is not bound to see to the execution of any trust, whether express, implied or constructive, to which any deposit made under the authority of this Act is subject'. This provision will not assist a bank which not only is aware that the funds are subject to a trust, but is also aware of any breach of that trust or circumstances suggesting such a breach. ${ }^{117}$

Because of the nature of the construction industry, most of the trustees of a builders' lien trust are corporations. When such a corporate trustee breaches the trust the question arises, especially when the corporation is insolvent, whether or not the officers and directors who are the controlling minds of the corporation have participated in the breach and should accordingly also be held liable to the beneficiaries. All of the provinces which have trust provisions in their respective builders' lien legislation have now included a provision making any officer or director of a corporation who knowingly assents or acquiesces in a breach of trust on the part of the corporation liable for the breach in addition to the corporation. Since many of the corporations handling trust funds in the construction industry are basically one-person operations, locating the "controlling mind" and imposing liability is usually not difficult and there are many cases with exactly this result. ${ }^{118}$ Also, it may be possible to sue the director or officer directly without suing the corporate trustee as well. ${ }^{119}$ While in most cases the breach in question has been committed by the contractor or a subcontractor, the provision applies to any trustee under the Act, including the owner. ${ }^{120}$ There is some speculation whether or not the provision contained in the statute pertaining to trustees found in most provinces which empowers the court to excuse a trustee who might be personally liable for a breach of trust who has acted in an honest and reasonable fashion ${ }^{121}$ is applicable to a statutory trust such as the builders' lien trust. Although no definitive answer has yet been offered, the B.C. Supreme Court did not see fit to relieve of liability directors who had committed what was described as an "innocent" breach of trust in Horsman Bros. Holdings Ltd. v. Panton. ${ }^{122}$

In addition to imposing liability on officers and directors, all the provincial builders' lien statutes containing trust provisions, with the exception of Ontario, also provide that breach of the builders' lien trust is a quasi-criminal offence. The penalties imposed by the various provinces range from a fine of not more than $\$ 5000$ or imprisonment for up to two years, or both, to a fine of up to $\$ 50,000$ or imprisonment for up to two years, or both. As mentioned above, one of the problems with

116. R.S.C. 1970 , c.B-1.

117. Fonthill Lbr. Ld. v. Bank of Montreal supra n. 109, Ross v. Royal Bank supra n.48, John Ritchie Limited; The Clarkson Co. Lid. v. Canadian Bank of Commerce et al. supra n.48, Perlmutter Shore Lid. v. Bank of Montreal supra n.48, Aetna Roofing (1965) Ld. v. Robinson (No. 2) [1971] 4 W.W.R. 191 (Man. Q.B.).

118. See Emco Supply, A Division of Emco Ld. v. Guegen et al. supra n.48, Henry Electric Ld. et al. v. Farwell supra n.48, Trilec Installations Ld. v. Bastion Const. Ldd. supra n.48, Edward Wilson et al. v. Parkin Enterprises Lid. supra n. 103.

119. Horsman Bros. Holdings Ldd. v. Dahl et al. supra n.48.

120. See Andrea Schmidt Const. Ldd. v. Glatt (1979) 25 O.R. (2d) 567, affm'd (1980) 28 O.R. (2d) 672 (C.A.).

121. The relevant provision in Alberta is s.41 of the Trustee Act, R.S.A. 1980, c.T-10.

122. [1976] 3 W.W.R. 745. 
the trust provisions addressed by the Manitoba Law Reform Commission in its 1979 report ${ }^{123}$ was the low fine imposed upon the commission of a breach of trust. Manitoba has since increased the fine to $\$ 50,000$ and a relatively low fine is now found only in British Columbia and New Brunswick. While Ontario did provide for an offence and penalty in its Mechanics' Lien Act, the provision was omitted from the present Construction Lien Act on the recommendation of the Advisory Committee to the Attorney General. The Committee felt that the Criminal Code provision relating to breach of trust was sufficient. Section 296 of the Criminal Code ${ }^{124}$ states that it is an indictable offence to convert trust funds with the intent to defraud and a person convicted of such is liable to imprisonment for up to fourteen years. To date there have been only two reported convictions under the Criminal Code which involve breach of a builders' lien trust. ${ }^{125}$ The advantage of prosecution under the provincial offence is, of course, that the Crown need not prove the intent to defraud. The provincial offence has been held in both British Columbia and Manitoba to be intra vires the provincial legislature and not in conflict with the section of the Criminal Code respecting criminal breach of trust. ${ }^{26}$

As for the time period in which an action for breach of trust may be commenced, British Columbia, New Brunswick and Ontario do not specify a limitation period in their respective builders' lien statutes. Ontario had included in its Mechanics' Lien Act a nine-month limitation period for trust claims against "a lender of money to a person upon whom a trust" was imposed. ${ }^{127}$ The Advisory Committee to the Attorney General was of the opinion that a special provision for the protection of money lenders was unwarranted and recommended that "the ordinary limitation periods, as well as the equitable doctrine of laches, should apply to such claims". The new Construction Lien Act in Ontario reflects this recommendation. Saskatchewan at one time provided for a 120 day limitation period. However, this has now been extended to one year from the time that the contract is completed or abandoned. ${ }^{128}$ It is not clear from the legislation whether the contract referred to is the overall contract or the contract into which the claimant had entered with his trustee. The limitation period in Manitoba is 180 days after the date upon which the person bringing the action first became aware of the breach of trust. ${ }^{129}$

An interesting argument with respect to the limitation period was raised in Albern Mechanical Ltd. et al. v. Toronto-Dominion Bank et al. ${ }^{130}$ The plaintiff subcontractor was suing the bank which had applied trust funds to the indebtedness of the contractor. The Ontario Mechanics' Lien Act provided at that time for a nine-month limitation period for actions claiming trust moneys from a money lender and the plaintiff had last supplied materials and services to the contractor some two years before the action was commenced. The plaintiff argued that the statute limited only

123. Supra n.26.

124. R.S.C. 1970 , c.C-34.

125. R. v. Brunner (1960) 32 W.W.R. 478 (B.C.C.A.) and Rosen v. The Queen (1985) 16 C.C.C. (3d) 481 (S.C.C.).

126. R. v. Brunner supra n. 125 and R. v. Serdom Const. Ldd. and Daumber [1983] 3 W.W.R. 318 (Man. Prov. Ct.).

127. R.S.O. 1970, c.267, s.4.

128. S.S. $1984-85-86$, c.B-7.1, s. 19 .

129. S.M. $1980-81$, c.7, s.8.

130. Supra n.46. 
a claim against the trust moneys per se and did not limit an action for damages for breach of trust. Mr. Justice Grange of the Ontario Supreme Court disposed of this argument by pointing out that a breach of trust could only arise out of the existence of trust property and the claimants could not have a claim for breach of trust unless they could also claim an interest in the trust property. The limitation period was, therefore, effective to bar both an action in personam and in rem.

The recommendations of the Task Force with respect to both the liability of officers and directors and sanctions for breach of trust are that a provincial offence for breach of trust should be created with significant fines and to which officers and directors of corporate trustees should also be liable. The Report of the Task Force does not contain a recommendation with respect to a special limitation period and it is presumed that the ordinary limitation period for breach of trust in Alberta would apply. At present in Alberta the Judicature Act provides that "no claim of a cestui que trust against his trustee for any property held on an express trust or in respect of a breach of the trust shall be held to be barred by a Statute of Limitations". ${ }^{131}$ Presumably, unless the statute expressly stated otherwise, a claim against a builders' lien trustee in Alberta could be brought at any time, subject to the doctrine of laches.

\section{APPRAISAL OF THE RECOMMENDATIONS OF THE TASK FORCE FOR ALBERTA}

The stated objective of the Task Force was to create a legislative framework which would provide greater assurance that everyone in the construction industry would be paid. How well would its recommendations accomplish that goal?

It is evident that the imposition of a trust scheme is effective. It is clear, as $\mathrm{Mr}$. Justice Rand pointed out in Minneapolis-Honeywell, ${ }^{132}$ that the lien is a limited remedy. The lien is really only effective against an owner who is unwilling or unable to pay his contractor. Once the owner has paid the contract price, the only mechanism to ensure that the funds stay within the construction chain is the trust. Once money is paid on the contract to the contractor or a subcontractor, he may not appropriate any of those funds to his own use until such time as he has paid in full all those with whom he has contractual privity. The trust imposed on funds in the hands of the owner ensures that the owner is not able to simply walk away from property, the value of which is less than the encumbrances.

While the imposition of a trust undoubtedly provides greater assurance of payment, it cannot solve the problems which arise when there is a shortage of funds in the construction chain. A shortage may occur either because the contractor underbid the job, or the contractor or a subcontractor fails to complete the project or complete it properly.

Where the contractor has underbid a job, there is little question that sub-trades and suppliers will bear the shortfall. In this situation the owner should not have to pay more than the contract price. The question is more difficult where there is a deficiency and the owner wishes to set off his damages against what is owing to the contractor. At first blush it appears that the principles involved should be the 
same, but somehow it is not as easy to justify the sub-trades and suppliers having to bear the loss while the owner never has to pay more than the contract price. It is a difficult problem because it is essentially the allocation of risk or deciding who will bear the loss. On one hand it seems reasonable that the sub-trades and suppliers should bear the loss because that is the risk of doing business. The purpose of builders' lien legislation is to facilitate the flow of funds so as to improve one's chance of being paid. The legislation does not, however, provide a guarantee of payment; it is not an insurance scheme. On the other hand, it is also possible to justify the loss being borne by the owner, if the contractor defaults, or the contractor, if a subcontractor defaults, because they are in a position to protect themselves by demanding from the contractor or subcontractor, as the case may be, a performance bond. Then, in the event of a deficiency, the loss is borme by the surety. As we have seen, in other provinces the issue has been resolved in favour of the owner and it is likely that Alberta will follow suit. It is not politically palatable to make the owner liable for more than the price for which he has contracted.

The consolation offered to sub-trades and suppliers in the past has been the statutory holdback as it has never been subject to set off. ${ }^{133}$ The holdback is cold comfort, however, as it represents at best a small percentage of the contract price when the flow of funds has been disrupted. When the contract funds are flowing smoothly, the holdback is still a detriment because no one gets paid in full until long after the project is complete. Since the holdback is of such small benefit to subtrades, the Task Force's proposal to eliminate it can be viewed as a step in the right direction. It will be interesting to see if the proposal is implemented, whether the holdback is effectively eliminated or if it is replaced by a contractual holdback, which may even exceed the former statutory holdback. After all, the prudent owner will not pay the full contract price until such time as he is fully satisfied with the job and that is often some time after the job has been completed. Certainly the Task Force report contemplates that there may be a contractual holdback. The advantage of a contractual holdback is, of course, its flexibility. Very stable contractors will likely be subject to no more than $5 \%$.

Another issue which is difficult to resolve is whether or not the beneficiaries of the builders' lien trust should be limited to those with whom the trustee has contractual privity (the privity of trust doctrine). It is evident why other provinces have adopted the privity of trust doctrine, but unfortunately they do not seem to have considered the solution to the problems inherent in not requiring privity of trust which was set out by the B.C. Court of Appeal in Mackenzie Redi-Mix. ${ }^{134}$ The main problem identified with not requiring privity of trust was uncertainty on the part of the trustee as to the identification of the beneficiaries. The solution provided by the B.C. Court of Appeal was that the trustee discharged his trust obligations simply by paying those with whom he had a contractual obligation to pay. As long as the funds kept flowing then the trustee would have no obligations or contact with

133. Although it is interesting to note that this was a judicial, rather than legislative imperative. See Russell v. French (1897) 28 O.R. 214 (C.A.), Baines v. Harman (1927) 60 O.L.R. 223 (C.A.), Lundy v. Henderson (1908) 9 W.L.R. 327 (Alta. C.A.), Milton Pressed Brick Co. v. Whalley (1918) 42 O.L.R. 200 (C.A.), Peart Bros. Hdwe. Co. v. Phillips (1915) 8 W.W.R. 1159 (Sask. C.A.), Cusson v. Myrtle S. Dist. [1921] 3 W.W.R. 479 (Man. C.A.), Coast Lighting Lid. v. Trend Bldg. Lid. (1970) 11 D.L.R. (3d) 735 (B.C.Co.Ct.).

134. Supra n.82. 
any other beneficiaries. If, however, the flow of funds was stopped somewhere along the chain, those who remained unpaid would have greater flexibility in reaching the funds at the point at which they stopped.

The Task Force has proposed that privity of trust be adopted, but it has also proposed an exception to it, namely the Stop Notice. The Task Force has obviously identified the need for flexibility in the system so the adoption of privity of trust seems somewhat an anomaly. Perhaps it was influenced by the trend in other provinces. The Stop Notice is an interesting concept. It is not found anywhere in Canada, but forms an integral part of the California lien system. The Stop Notice provides a convenient method for unpaid sub-trades and suppliers to stop the flow of funds from the owner if they believe the funds have been or may be diverted to unauthorized uses somewhere along the chain. Clearly it is in the best interest of everyone in the chain to keep the funds flowing. It is therefore likely that the Stop Notice would be used only if there is a serious problem.

There are a number of problems with the Stop Notice which must be addressed if it is to be an effective remedy. First, when served with a Stop Notice the owner should, if there are funds owing under the contract, set aside those funds up to the amount claimed in the Stop Notice. The funds should not, however, be paid by the owner to the person claiming same in the Stop Notice. There are two reasons for this: 1) the amount claimed in the Notice may be in excess of what the party claiming is actually owed, and 2) if that beneficiary is paid in full it will likely cause a deficiency for other claimants and the beneficiary serving the Notice will end up in a preferred position over other unpaid claimants. The better solution would be for there to be a period during which the parties have an opportunity to resolve the matter and withdraw the Stop Notice. This would permit the parties to deal with an isolated claim without disrupting the flow of funds. If, however, the matter cannot be resolved, the funds should be paid into court. Once the funds are paid into court all unpaid beneficiaries should be able to assert a claim and all share pari passu in the proceeds. By requiring that the funds be paid into court one can be assured that Notices will not be served for frivolous reasons. Indeed the Task Force may wish to consider a penalty for filing a frivolous Stop Notice which is similar to that for filing an exaggerated lien.

Essentially the Notice will be of the same consequence as filing a lien. However, the Notice does not tie up the owner's title and those beneficiaries who might otherwise not be entitled to a lien will have a remedy. A matter which does not seem to be addressed by the Task Force is the interaction of liens and claims pursuant to a Stop Notice and the priority of each. The Ontario Construction Lien Act provides that where a trustee is insolvent, priority is to be given to those trust beneficiaries who have proved a lien. ${ }^{135}$ In the writer's opinion, it is neither necessary nor desirable to prefer lien claimants over trust claimants. The effect of such a preference is to encourage the filing of liens and increase the aggravation of the owner. Instead, both lien and trust claimants should share rateably in whatever proceeds there are and both lien and trust claimants should be able to join in any action which has been commenced and be given an opportunity to prove their claim. Once funds have been stopped and are paid into court then it only makes sense to deal with the claims of all unpaid claimants at the same time and there does not seem to be a persuasive reason why a lien should receive priority. 
Indeed, for the Stop Notice to operate most effectively, the lien remedy should be available only to the contractor. Subcontractors and suppliers would be adequately protected by relying on their trust claims. If an owner was refusing or neglecting to pay, then the contractor would file a lien and, if payment were still not forthcoming, the land would be subject to foreclosure and the proceeds would be subject to a trust in favour of all those down the chain behind the contractor. If, on the other hand, the problem was with the contractor, either he was insolvent, diverting funds or refusing to pursue the lien remedy, trust beneficiaries could attach funds in the hands of the owner by serving a Stop Notice and bypass the contractor. In this situation alone it would make sense for trust claimants to have priority over the lien if both were filed since had the money gone to the contractor, it would be subject to a trust in favour of the claimants in any event. At present the Stop Notice is an intriguing, but unrefined concept. It has potential, but would mean a marked departure from the privity of trust doctrine. It will be interesting to see how the Task Force deals with it in its final report and draft legislation.

As we have seen, while the trust provisions are effective at keeping funds within the chain, as soon as funds stop flowing or there is a deficiency problems arise for which the trust does not provide a solution. It is essential, therefore, to keep the funds flowing. For this reason the Task Force recommendations of both registration and the requirement of a separate trust account are of the utmost importance. Registration means that persons handling trust funds will have to demonstrate at least a basic knowledge of the obligations of a builders' lien trustee. It also means that a contractor or subcontractor will be "permitted" to be dishonest only once. This assumes, of course, that the registration will be of individuals, so that the dishonest cannot hide behind an ever-shifting corporate veil. The requirement that one must be registered to claim the benefit of the Act or enforce his contract should be very effective in cleaning up the industry so that in time only honest, reputable contractors and subcontractors will be operating with fewer ensuing problems for both owners and sub-trades.

Similarly the requirement of a separate trust account should help rectify a number of practices such as paying past accounts or financing new projects with current receipts which contribute to the instability of the industry. The requirement of a separate trust account may seem onerous to those contractors and subcontractors who rely on the ability to borrow funds using accounts receivable as collateral. This is less of a problem than it appears for two reasons: 1) if the bank is lending money on the basis of accounts receivable, it is already taking into account the customer's accounts payable and basically the trust obligations are the accounts payable, and 2 ) if the money is lent for the purpose of paying trust beneficiaries, the customer is able to repay the bank from trust funds without committing a breach of trust. Of course, the requirement of a separate trust account will not prevent a trustee from paying trust funds into another account for his own use. In that situation a bank which is in receipt of the funds will have little trouble establishing that it was not aware of the nature of the funds and received them in the ordinary course of business. All in all, however, these two requirements which are unique in Canada will have a profound effect on the construction industry and should be of great benefit to all involved. 


\section{CONCLUSION}

While the imposition of a trust scheme on the construction industry in Alberta will be of great benefit to sub-trades and suppliers by ensuring that funds remain within the construction chain, the trust is unable to solve every problem. In the situation where there is a deficiency of funds the loss must be borne by one party or another. Even though the stated intention of builders' lien legislation is to protect the interests of subcontractors, materialmen and labourers, where there is a deficiency of funds the loss usually falls on them. The strength of the Task Force's Preliminary Report lies in its recommendation of registration for contractors and subcontractors and the requirement of a separate consolidated trust account. These two recommendations are unique in Canada and reflect a certain degree of boldness on the part of the Task Force. If implemented there should be fewer defalcations and fewer interruptions in the flow of moneys down the construction chain from which all involved should benefit, but especially sub-trades and suppliers. For this reason alone the recommendations of The Task Force should be given serious consideration. 